\title{
Estratigrafia e tectônica da seção rifte no Gráben de Camamu, porção emersa da Bacia de Camamu, Bahia
}

\author{
Christian C. Born', Claiton M. S. Scherer ${ }^{2}$, Felipe Adegas ${ }^{2}$, \\ Mário de Lima Filho ${ }^{4}$ \& Juliano Küchle ${ }^{2}$
}

\begin{abstract}
Resumo O Gráben de Camamu corresponde à extremidade sul de um sistema de grábens conectados limitado pelo sistema de falhas de Maragogipe. Evidências estruturais e estratigráficas indicam que os depósitos deste gráben foram controlados por tectônica rifte. Foram reconhecidas duas sequências deposicionais. A base da Sequência I é composta por leques aluviais provenientes da margem leste, depositados durante a rotação do embasamento. Estes leques eram dominados por fluxos gravitacionais e por canais entrelaçados rasos com dunas eólicas subordinadas. A drenagem principal era caracterizada por canais entrelaçados profundos que fluíam para ENE, transpassando os altos estruturais da margem leste. O padrão agradacional e as características arquiteturais do sistema fluvial caracterizam um trato de sistemas de baixa acomodação. Sobre estes depósitos se estabelece um sistema fluvial distributário, caracterizado por canais fluviais de carga mista que perdem grande parte de sua energia em direção as suas porções distais, onde dominam inundações em lençol de baixa energia em uma planície de inundação com lagos efêmeros. O padrão de empilhamento retrogradacional é atribuído ao aumento nas taxas de subsidência tectônica. A Sequência II marca um rápido avanço do sistema distributário após uma erosão generalizada da planície de inundação causada pela queda no nível de base. Esta sequência é composta por canais fluviais de carga de fundo com preenchimento multiepisódico, que se intercalam com depósitos de inundações em lençol arenosas e dunas eólicas subordinadas. A arquitetura fluvial e o padrão agradacional indicam condições de baixas taxas de acomodação.
\end{abstract}

Palavras-chave: Bacia de Camamu, seção rifte, estratigrafia.

\begin{abstract}
Stratigraphy and tectonics of the rift stage in Camamu Graben, onshore Camamu Basin, Bahia. Camamu Graben corresponds to the southern portion of a connected graben system bounded by Margogipe's Fault System. Structural and stratigraphic evidences reveal that the deposits within this graben were controlled by rift related tectonics. Stratigraphic analysis allowed the recognition of two unconformity-bounded sequences. The base of Sequence I is composed by alluvial fans coming from the east margin and deposited during basement rotation. These systems were dominated by gravitational flow or braided channels, with subordinated aeolian dunes. The main drainage was characterized by a deep braided channel system, which flowed eastward, transposing the structural high of the east margin. The agradational stacking pattern and the fluvial architectural characteristics marks a low accommodation systems tract. Above these deposits takes place a distributary fluvial system, characterized by mixed load rivers and in its distal portion by sheet floods in a muddy flood plain with ephemeral lakes. The retrogradational stacking pattern is attributed to an increase on subsidence rates. Sequence II marks the ongoing of the distributary system basinward after a generalized erosion of the flood plain deposits caused by a base level fall. This sequence is composed by bed load channels interlayered with sandy sheet floods and subordinated aeolian dunes. The fluvial architecture and the agradational stacking pattern suggest low accommodation conditions.
\end{abstract}

Keywords: Camamu Basin, rift, stratigraphy.

INTRODUÇÃO A seção rifte das bacias brasileiras representa o registro sedimentar associado aos primeiros estágios de ruptura do Gondwana. Este registro gerou importantes sistemas petrolíferos do país e, apesar de sua importância, ainda não é adequadamente conhecido em termos estratigráficos e sedimentológicos.

Apesar dos inúmeros trabalhos sobre estratigrafia e tectônica da fase rifte, até hoje não se tinha conhecimento sobre a existência destes depósitos na porção emersa da Bacia de Camamu. Isto se deu por causa de alguns fatores, entre os quais se podem destacar: (i) a falta de dados paleontológicos e geocronológicos, (ii) a complexidade estrutural, (iii) a dificuldade de encontrar bons afloramentos e (iv) o uso da litoestratigrafia como ferramenta prioritária. Por esses motivos, os depósitos aqui associados à fase rifte haviam

1 - PETROBRAS, UO-ES/ENGP, Vitória (ES), Brasil. E-mail: cristao_geo@yahoo.com.br

2 - Instituto de Geociências, Universidade Federal do Rio Grande do Sul, Porto Alegre (RS), Brasil. E-mail: claiton.scherer@ufrgs.br; searchforadegas@yahoo.com; julianokuchle@yahoo.com.br

3 - Instituto de Geociências, Universidade Federal de Pernambuco, Recife (PE), Brasil. E-mail: mflf@ufpe.br 
sido anteriormente interpretados como pertencentes ao Grupo Brotas, fase pré-rifte de evolução da bacia (e.g. CBPM 2006).

O estudo estratigráfico detalhado nos arredores da cidade de Camamu revelou uma complexa inter-relação entre tectônica extensional, erosão e sedimentação no desenvolvimento desta peculiar região da Bacia de Camamu. Neste trabalho serão apresentados dados sedimentológicos, estratigráficos, estruturais, paleontológicos e interpretações que explicam como estes depósitos foram associados à fase rifte e como foi sua evolução ao longo do tempo.

CONTEXTO GEOLÓGiCO A Bacia de Camamu localiza-se no litoral centro-sul da Bahia. Seu limite norte com as bacias do Recôncavo e de Jacuípe é dado pela Falha da Barra (Fig. 1A). Ao sul, o limite com a Bacia de Almada é definido pelo alto de Taipus. O limite oeste é dado pelo Sistema de Falhas de Maragogipe, que coloca as rochas sedimentares em contato direto com o embasamento.

A evolução estratigráfica da Bacia de Camamu, assim como nas demais bacias da margem leste brasileira, é caracterizada por quatro fases geotectônicas associadas à ruptura do Gondwana e formação do Oceano Atlântico (Asmus \& Porto 1980): pré-rifte (Neojurássico ao Eocretáceo); rifte, (Neocomiano ao Aptiano); transicional ou de golfo proto-oceânico (Aptiano), e deriva continental (Albiano ao recente).

Segundo Caixeta et al. (2007), a sedimentação pré-rifte é composta pelos depósitos fluviais e lacustres da Fm. Aliança, pelos ciclos flúvio-eólicos da Fm. Sergi e pelos depósitos deltaicos, flúvio-eólicos e lacustres e das formações Itaparica, Água Grande e Candeias (Membro Tauá).

A fase rifte compreende rochas do Grupo Almada (formações Morro do Barro e Rio de Contas) e da porção basal do Grupo Camamu (parte da Fm. TaipusMirim). Segundo Caixeta et al. (2007), a Fm. Morro do Barro tem sua origem vinculada a depósitos de fluxos gravitacionais subaquosos em um lago tectônico durante o Andar Rio da Serra, enquanto que a Fm. Rio de Contas é representativa de depósitos de leques aluviais, rios e lagos que se instalaram durante os andares Aratu, Buracica e Jiquiá. A Fm. Taipus-Mirim é representativa de uma sedimentação flúvio-deltáica (Caixeta et al. 2007).

METODOLOGIA A análise estratigráfica compreendeu o levantamento de seções colunares na escala 1:100 em treze afloramentos. As interpretações dos sistemas deposicionais e estilos fluviais foram fundamentadas na descrição detalhada das fácies, nas seções colunares e em painéis laterais de afloramentos-chave. Uma seção composta foi construída a partir do empilhamento estratigráfico dos afloramentos levando-se em conta sua posição espacial e o mergulho das camadas. Esta seção permitiu identificar os padrões de empilhamento e as superfícies-chave. As interpretações estruturais foram feitas com base nos dados de campo, no mapa de anomalias gravimétricas, em fotografias aéreas na escala 1:60.000 e em imagens de radar.

GEOLOGIA ESTRUTURAL A tectônica rifte imprimiu na Bacia de Camamu uma série de blocos altos e baixos alongados na direção N-S (Fig. 1A). Estes blocos podem ser facilmente observados no mapa de anomalia gravimétrica residual Bouguer (Fig. 2).

O Gráben de Camamu Na porção oeste da Bacia de Camamu, o Sistema de Falhas de Maragogipe, formado por uma série de falhas menores que se conectam, controla um longo sistema de grábens interconectados denominado aqui Gráben de Maragogipe (Fig. 1A). A área de estudo deste trabalho localiza-se na extremidade sul do Gráben de Maragogipe, onde um destes grábens menores, denominado Gráben de Camamu, pode ser individualizado (Fig. 1B). Este segmento conectase com outros pequenos grábens, que podem ser individualizados por altos transversais do embasamento no hangingwall (Fig. 2).

O limite oeste do Gráben de Camamu é dado pela Falha de Igrapiúna. Na sua porção leste, as rochas da bacia estão em contato por não conformidade com uma rampa do embasamento com mergulho para NW. Esta rampa se prolonga para leste até a Falha de Camamu Oeste. Esta falha, em conjunto com a Falha de Camamu Leste, configura o chamado Alto de Camamu (Fig. 1B), uma feição geomorfológica bastante evidente, que faz as rochas embasamento aflorarem até cerca de $1 \mathrm{~km}$ a norte do município de Camamu. Dados gravimétricos sugerem que este alto se mantém em subsuperfície para norte até o sul da Ilha de Boipeba, onde se conecta com o Alto de Tinharé (Fig. 2).

Na porção norte do Gráben de Camamu, ocorre uma série de lineamentos de direção $\mathrm{N} 45^{\circ} \mathrm{W}$. A norte destes lineamentos, o embasamento do Alto de Camamu não mais aflora, sugerindo que eles se comportem como falhas normais com mergulho para NE. Os dados gravimétricos sugerem que, para norte, o Gráben de Camamu se comporta como uma rampa que se aprofunda gradativamente (Fig. 2).

As camadas geralmente apresentam mergulhos moderados a baixos para NW e por vezes para SE (na porção oeste do gráben). A seção geológica $\mathrm{ABC}$ (Fig. 1C) mostra que o Gráben de Camamu apresenta geometria de meio-gráben, com a falha de borda a oeste e com uma rampa falhada a leste.

FÁCIES Foram individualizadas doze diferentes fácies, identificadas pela combinação de granulometria e estruturas sedimentares. Para todas as fácies foi atribuído um código e uma interpretação em termos de processos sedimentares, seguindo a proposta de Miall (1996) (Tab. 1).

ARCABOUÇO ESTRATIGRÁFICO O pacote sedimentar analisado pôde ser dividido em três intervalos estratigráficos informais: (i) basal, (ii) intermediário e (iii) superior (Fig. 3), compostos por associações 


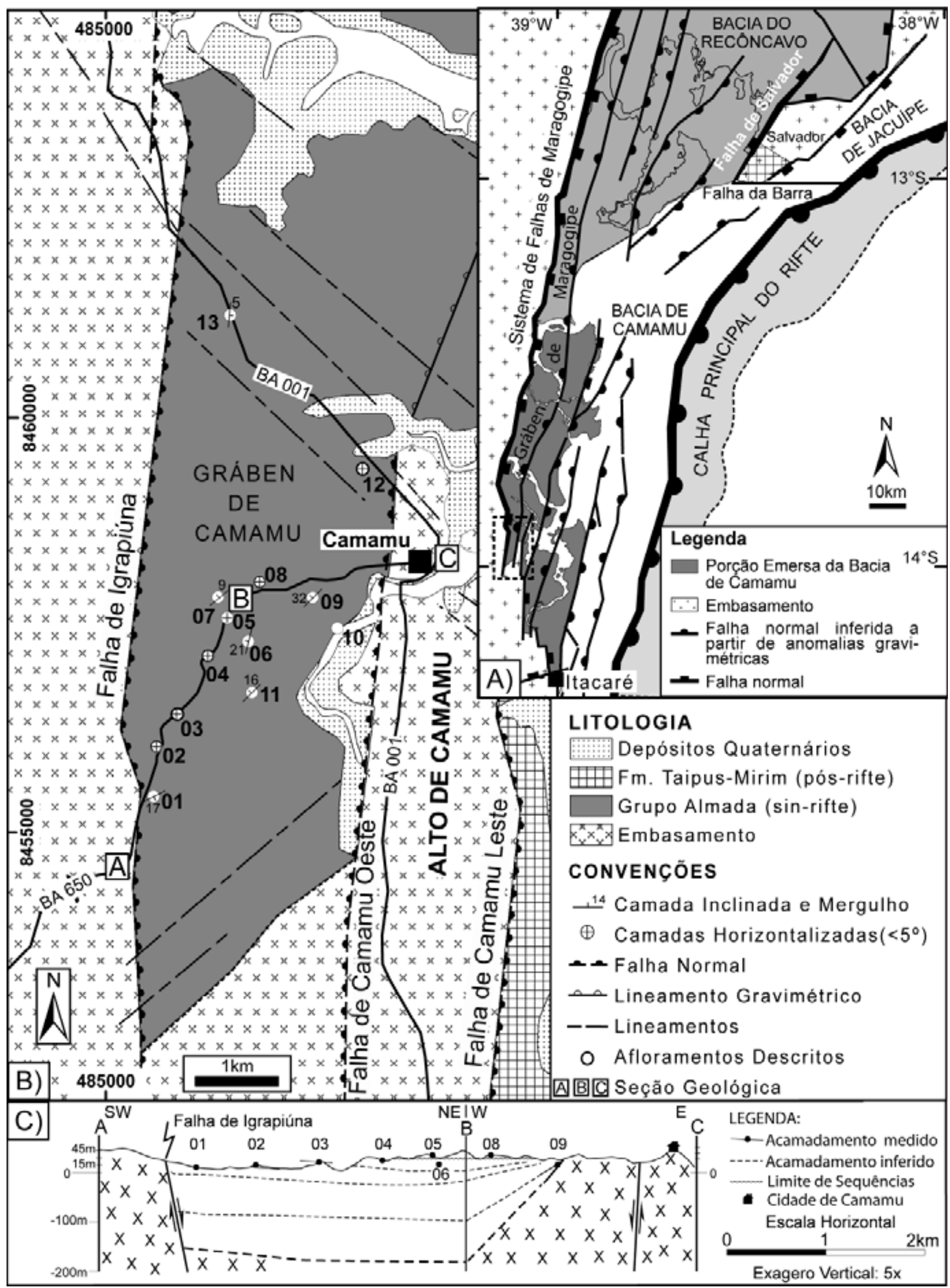

Figura 1 - A) Mapa estrutural da Bacia de Camamu. Área de estudo no retângulo pontilhado. B) Mapa geológico da área de estudo mostrando as principais feições estruturais e geomorfológicas. C) Seção geológica A-B-C mostrando geometria de meio-gráben. 


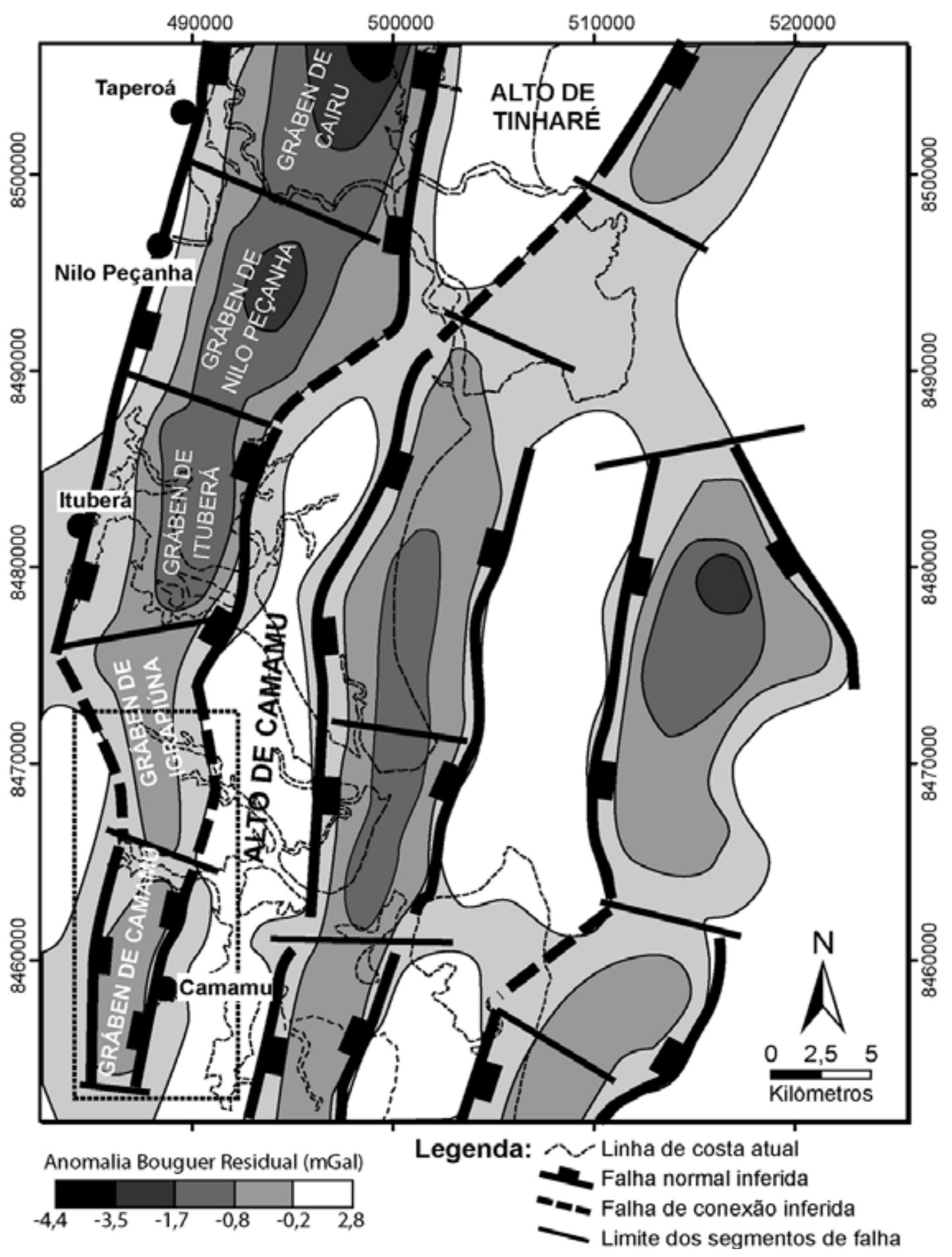

Figura 2 - Mapa estrutural interpretado a partir de anomalias gravimétricas. À esquerda, observa-se o sistema de grábens conectados do qual o Gráben de Camamu faz parte. No centro e à direita, são observados mais dois sistemas de grábens conectados. Área de estudo limitada pelo retângulo pontilhado.

de fácies (AF) distintas, refletindo diferentes estágios de preenchimento do Gráben de Camamu, conforme será discutido a seguir.

Intervalo Basal Este intervalo apresenta espessura mínima de $50 \mathrm{~m}$ e é composto por quatro associações de fácies: leques aluviais, fluviais entrelaçados profundos, fluviais entrelaçados rasos e dunas eólicas.
Associação de Fácies 1 - Leques Aluviais Camadas tabulares com base abrupta não erosiva, compostas por conglomerados matriz-suportados (Gmm) com blocos e seixos angulosos de metagranitos (Fig. 4A). Mais raramente ocorrem conglomerados intraclásticos formados essencialmente por clastos de pelitos (Fig. 4B). Estas litofácies ocorrem justapostas lateral e verticalmente a conglomerados maciços clasto-suportados 
$(\mathrm{Gcm})$, pobremente selecionados, variando de areia média até matacões (Fig. 5D). Os clastos são angulosos, compostos por metagranitoides e ortognaisses, com diâmetro de até $70 \mathrm{~cm}$. No afloramento 09 é possível visualizar estes conglomerados diretamente sobre o embasamento, formando uma cunha que se espessa para NW e se adelgaça para SE, onde "onlapa" contra a não conformidade (Fig. 5).

INTERPRETAÇÃO Os conglomerados matriz-suportados e os conglomerados intraformacionais são interpretados como depósitos de fluxos de detritos plásticos, gerados por movimentos de massa altamente coesivos. Os conglomerados maciços clasto-suportados representam fluxos de detritos pseudoplásticos, hiperconcentrados, viscosos e turbulentos (Miall 1996). De acordo com Miall (1996), estas fácies são típicas de fluxos gravitacionais, o que permite inferir a presença de um relevo significativo nas proximidades. A natureza angulosa e baixa maturidade composicional dos clastos indicam curtas distâncias de transporte. A geometria em cunha e a progressiva diminuição do basculamento das camadas para o topo da seção indicam que estas fácies se depositaram durante a progressiva rotação do embasamento.

Associação de Fácies 2 - Fluviais entrelaçados profundos Ocorre sobre os depósitos da associação de fácies de leques aluviais e consiste de corpos arenosos multiepisódicos, formando ciclos de granodecrescência com até $6 \mathrm{~m}$ de espessura. Estes corpos intercalam-se lateral e verticalmente com descontínuas camadas de pelitos laminados (Fig. 5A). A base de alguns corpos arenosos é fortemente erosiva e apresenta lags conglomeráticos contendo esparsos blocos angulosos de metagranitoides e intraclastos argilosos. Estes lags são sobrepostos por conglomerados com estratificações cruzadas acanaladas (Gt) ou com laminações horizontais (Gh), sobrepostos por arenitos médios a grossos, geralmente conglomeráticos, com estratificações cruzadas acanaladas $(\mathrm{St})$ ou laminações plano-paralelas (Sh). Os sets de estratos cruzados apresentam espessuras de até $2 \mathrm{~m}$. Em direção ao topo dos ciclos, ocorre uma diminuição das fácies $\mathrm{Gt}$ e $\mathrm{Gh}$ em relação às fácies St e Sh. Os dados de paleocorrentes indicam transporte para ENE (Fig. 5B).

INTERPRETAÇÃO A presença de corpos limitados por superfícies erosivas côncavas e preenchidos por arenitos e conglomerados, arranjados em ciclos de granodecrescência, sugere que esta associação de fácies represente depósitos de canais fluviais. As superfícies erosivas de base dos corpos arenosos são interpretadas como superfícies de $5^{\mathrm{a}}$ ordem (terminologia de Miall 1988) e representam os limites basais dos canais principais. Os sets de estratos cruzados de grande porte devem representar barras arenosas de meio de canal.

Tabela 1 - Fácies identificadas durante os trabalhos de campo e sua interpretação.

\begin{tabular}{|c|c|c|c|}
\hline Código & Fácies & Estrutura & Interpretação \\
\hline $\mathrm{Gmm}$ & Cascalho matriz-suportado & Maciço & Fluxo de detritos plásticos \\
\hline $\mathrm{Gcm}$ & Cascalho clasto-suportado & Maciço & Fluxo de detritos pseudoplásticos \\
\hline Gh & Cascalho clasto-suportado & Acamamento horizontal, imbricamento & $\begin{array}{l}\text { Formas de leito longitudinais, } \\
\text { depósitos residuais (lags) }\end{array}$ \\
\hline Gt & Cascalho estratificado & Estratificações cruzadas acanaladas, gradação normal & $\begin{array}{l}\text { Migração de barras cascalhosas } \\
\text { transversais de crista sinuosa }\end{array}$ \\
\hline Sh & Areia fina a muito grossa & Laminação horizontal & $\begin{array}{l}\text { Formas de leito planas (regime de } \\
\text { fluxo superior) }\end{array}$ \\
\hline Sl & Areia fina a muito grossa & Laminação de baixo ângulo $(<15 \%)$ & $\begin{array}{c}\text { Preenchimento de suaves } \\
\text { depressões, dunas atenuadas }\end{array}$ \\
\hline $\mathrm{Sm}$ & Areia fina a muito grossa & Maciça ou laminação indistinta & $\begin{array}{l}\text { Fluxos hiperconcentrados, } \\
\text { fluidizações }\end{array}$ \\
\hline St & $\begin{array}{l}\text { Areia fina a muito grossa } \\
\text { (podendo ser cascalhosa) }\end{array}$ & Estratificações cruzadas acanaladas & $\begin{array}{l}\text { Migração de dunas subaquosas } \\
\text { com cristas sinuosas }\end{array}$ \\
\hline $\mathrm{Sr}$ & Areia muito fina a grossa & Laminações cruzadas de marcas onduladas & $\begin{array}{l}\text { Migração de marcas onduladas } \\
\text { subaquosas por fluxo unidirecional }\end{array}$ \\
\hline $\mathrm{F} 1$ & $\begin{array}{l}\text { Areia muito fina, silte ou } \\
\text { lama }\end{array}$ & $\begin{array}{c}\text { Laminações horizontais, laminações cruzadas de marcas } \\
\text { onduladas }\end{array}$ & $\begin{array}{l}\text { Decantação de finos ou correntes } \\
\text { trativas de muito baixa energia }\end{array}$ \\
\hline $\mathrm{Fm}$ & Silte, lama & $\begin{array}{l}\text { Maciço, pode conter gretas de contração ou agregados } \\
\text { esferoidais }\end{array}$ & $\begin{array}{l}\text { Depósitos por decantação, } \\
\text { exposição subaérea, solos } \\
\text { incipientes }\end{array}$ \\
\hline $\mathrm{St}(\mathrm{e})$ & $\begin{array}{l}\text { Areia fina a grossa, } \\
\text { bimodal, estratificada }\end{array}$ & $\begin{array}{l}\text { Estratificação cruzada acanalada de grande porte } \\
\text { composta por laminação gerada pela migração de } \\
\text { marcas onduladas eólicas }\end{array}$ & Depósitos de dunas eólicas \\
\hline
\end{tabular}




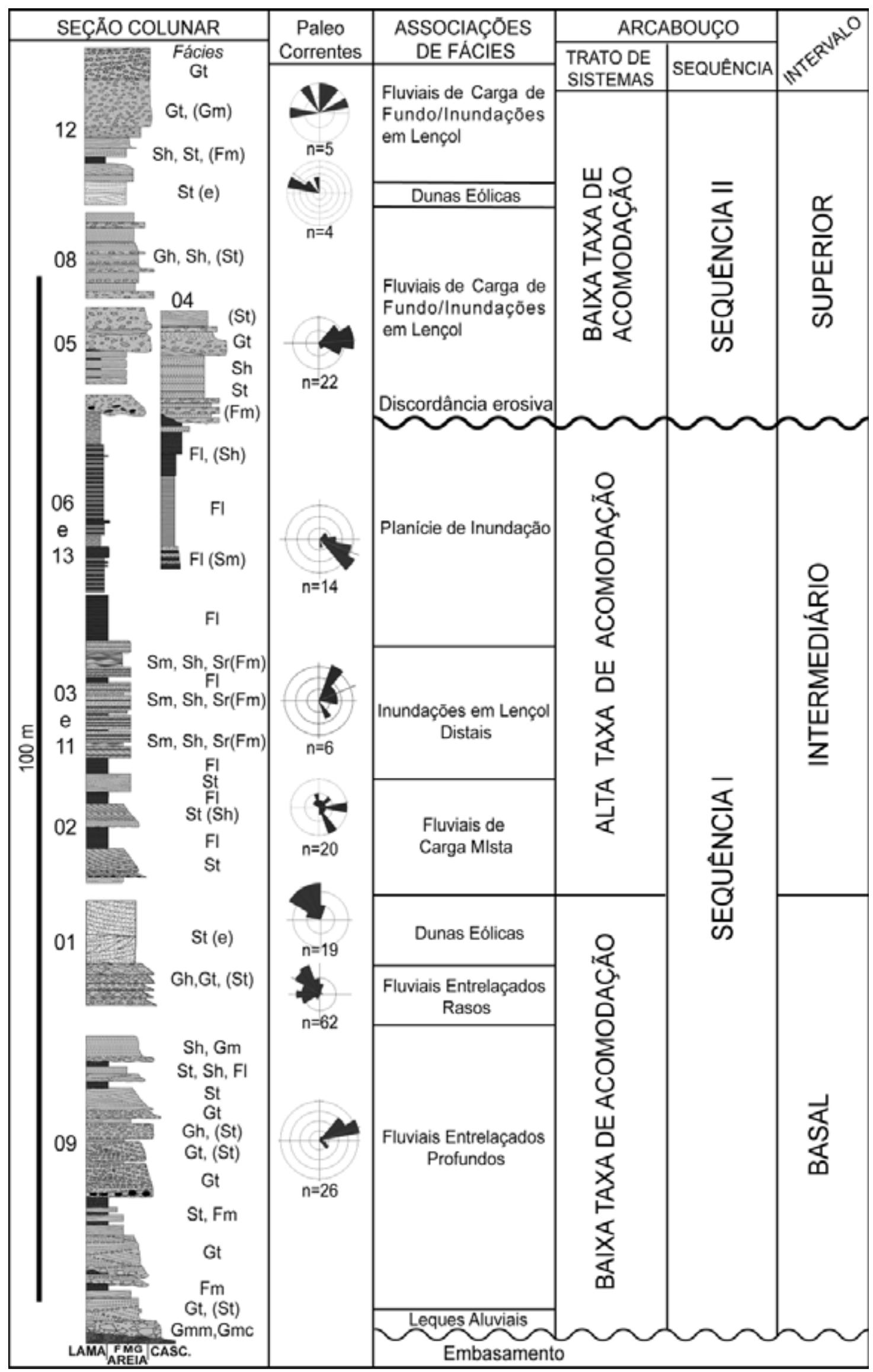

Figura 3 - Seção colunar composta a partir dos afloramentos, diagramas de paleocorrentes, sistemas deposicionais e arcabouço estratigráfico. Os números próximos à coluna indicam os afloramentos. 

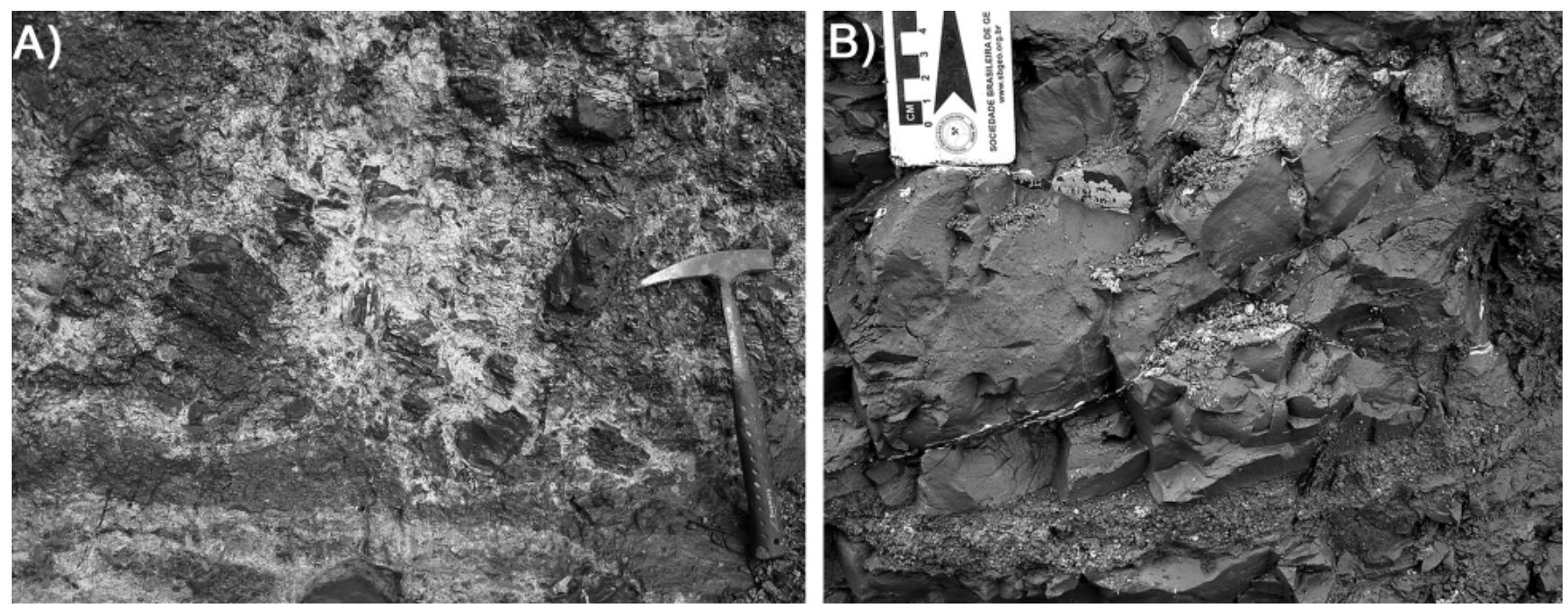

Figura 4 - Depósitos de fluxos de detritos. A) Clastos flutuando em matriz lamosa e lente de conglomerado maciço. B) Conglomerado intraformacional com seixos e blocos pelíticos em matriz lamosa.

A natureza acanalada da base dessas barras indica que estão preenchendo depressões de fundo de canal (hollows) (Siegenthaler \& Huggenberger 1993, Miall 1996). A natureza grossa dos sedimentos, a presença de barras de meio de canal e a baixa dispersão das paleocorrentes sugerem canais fluviais entrelaçados. A espessura de até $2 \mathrm{~m}$ das formas de leito e o alto grau de incisão indicam canais profundos. A predominância de fácies arenosas em lugar das conglomeráticas sugere áreas-fonte relativamente distantes. A presença

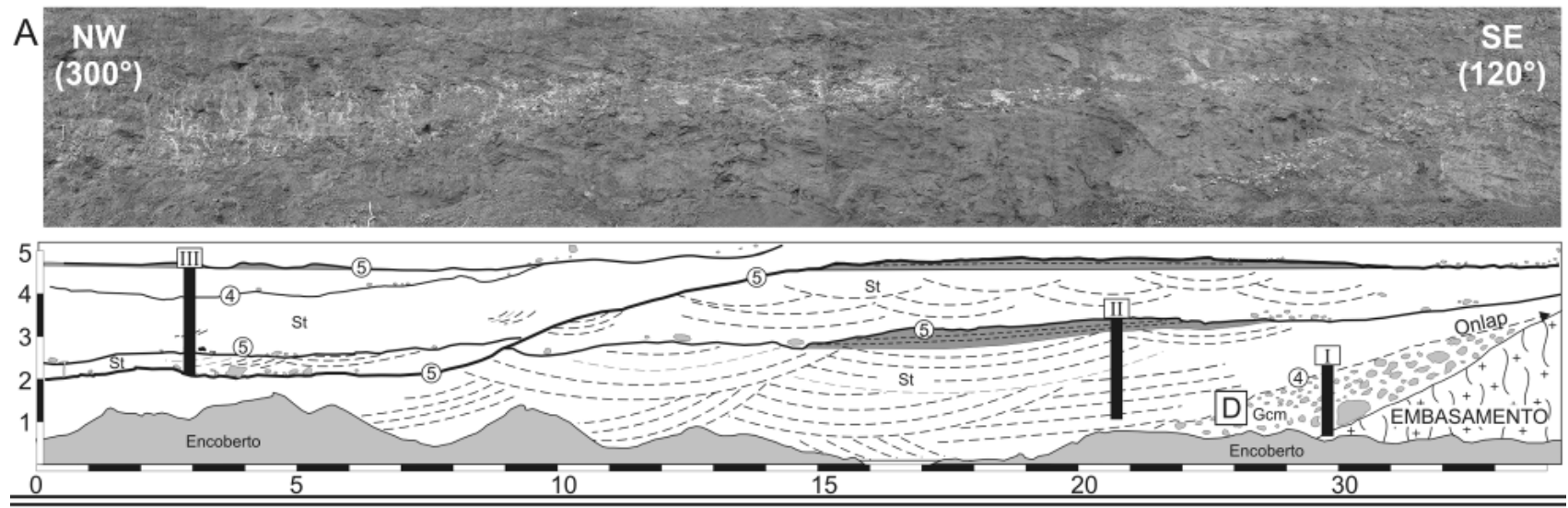

Associações de Fácies Fluvial entrelaçado profundo Cinturão de canais
Planície de inundação Leque aluvial

50: Fluxo de detritos pseudoplástico

Superfícies Fluviais

(4) 5 Superfícies de $4^{\mathrm{a}}$ e $5^{\mathrm{a}}$

5 ordem (Miall 1988, 1996)

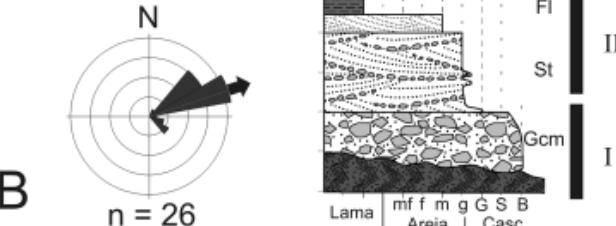

B
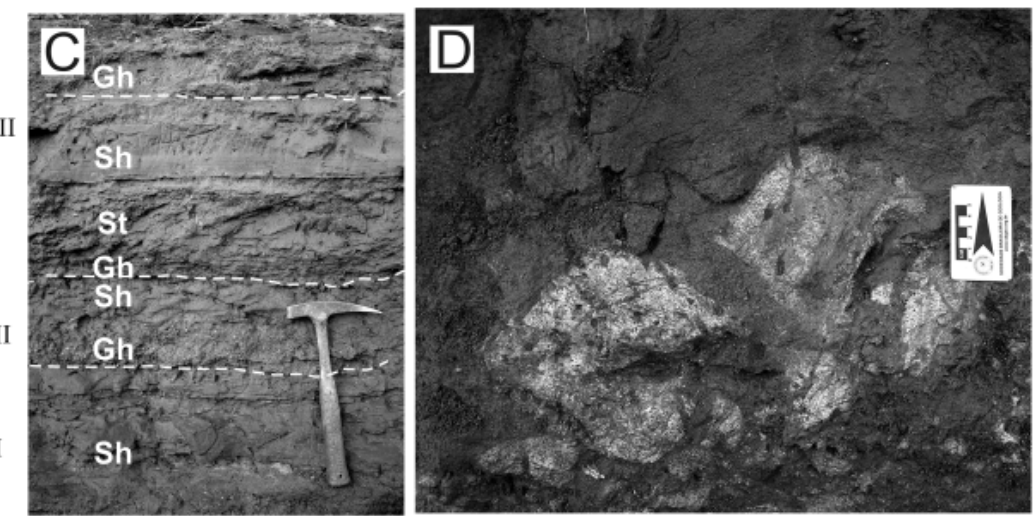

Figura 5 - Ponto 09. A) Fotomosaico e interpretação do afloramento, mostrando um complexo de canais amalgamados. B) Seção colunar composta, levantada em três pontos do afloramento (I, II e III), e diagrama de paleocorrentes. C) Detalhe dos ciclos menores. D) Blocos e matacões angulosos do embasamento no conglomerado basal. 
de blocos esparsos nos lags basais pode estar associada ao retrabalhamento dos depósitos da associação de fácies de leques aluviais, sobre a qual esta associação de fácies ocorre (Fig. 5A). Os pelitos são interpretados como depósitos de planície de inundação.

\section{Associação de Fácies 3 - Fluviais entrelaçados rasos Composta por camadas tabulares de conglomerados a seixos (Figs. 6C e 5D), subangulosos a subarredonda- dos, moderadamente selecionados, variando de areia grossa até blocos. Os clastos são de metagranitos e geralmente apresentam-se imbricados. As camadas formam ciclos de granodecrescência com 0,3 a $0,5 \mathrm{~m}$ de espessura, compostos por apenas uma fácies ( $\mathrm{Gh}$ ou $\mathrm{Gt}$ ) ou por duas (Gt-St) (Fig. 6B). A fácies St ocorre de forma subordinada como delgadas lentes. Os contatos basais dos ciclos são planares não erosivos. Os dados de paleocorrentes obtidos principalmente a partir dos clastos imbricados indicam transporte para NW (Fig. 6A). Esta associação de fácies ocorre abaixo de depósi- tos de dunas eólicas (Fig. 6A).}

INTERPRETAÇÃO A predominância de conglomerados com geometria tabular, arranjados em ciclos de granodecrescência, sugerem deposição por sistemas fluviais entrelaçados pobremente canalizados a desconfinados. A ausência de macroformas e a pequena espessura dos ciclos sugerem canais rasos. A ausência de fácies pelíticas pode estar relacionada com a grande mobilidade lateral dos canais, que provavelmente formavam uma rede de canais instáveis (Miall 1996).

Associação de Fácies 4 - Dunas eólicas Esta associação é composta por arenitos bimodais, médios a muito grossos, arranjados em sets de estratos cruzados acanalados com 3 a $5 \mathrm{~m}$ de espessura (Fig. 6A), separados por superfícies côncavas. Internamente, os sets são compostos por laminação com gradação inversa (Fig. 7). Localmente, ocorrem estratificações compostas, onde sets de estratos cruzados menores são limitados por superfícies inclinadas que mergulham na mesma direção que os forests das estratificações maiores (Fig. $6 \mathrm{C})$. Os estratos cruzados apresentam um mergulho principal para NW (Fig. 6A).

INTERPRETAÇÃO Os sets de estratos cruzados acanalados de grande porte internamente compostos por laminações com gradação inversa são interpretados como depósitos residuais de dunas eólicas. As lâminas com gradação inversa que compõem os estratos cruzados são interpretadas como depósitos de marcas onduladas eólicas. A ocorrência exclusiva de marcas onduladas eólicas indica dunas severamente truncadas ou com uma face de escorregamento fracamente desenvolvida (Kocurek 1996, Scherer 2000). As superfícies côncavas que limitam os sets são interpretadas como superfícies de $1^{\mathrm{a}}$ ordem (Brookfield 1984). A geometria acanalada destas superfícies indica dunas eólicas crescentes com cristas sinuosas. As superfícies inclinadas que dividem cosets de estratos cruzados compostos são interpretadas como superfícies de $2^{\mathrm{a}}$ ordem (Brookfield 1984), formadas pela migração de dunas menores na face frontal da forma de leito principal (draas).

\section{MODELO DEPOSICIONAL DO INTERVALO}

BASAL $O$ modelo proposto para este intervalo consiste em um sistema de leques aluviais provenientes da margem leste da bacia, caracterizada por uma rampa com mergulho para NW. O sistema de leques é caracterizado pela coexistência de dois estilos fluviais distintos. O primeiro consiste de depósitos gerados por fluxos gravitacionais e depósitos derivados da desaceleração destes fluxos (AF-1). No segundo tipo predominam leitos cascalhosos trativos, e os depósitos gravitacionais são raros ou ausentes (AF-3). Os leques fluíam para NW, possivelmente controlados pelo basculamento local da bacia (Fig. 8).

Períodos de não deposição permitiram que porções destes leques fossem retrabalhadas por ventos provenientes de $\mathrm{SE}$, gerando dunas eólicas (AF-4).

A drenagem principal da bacia é caracterizada por um sistema de canais entrelaçados profundos (AF2) que fluem para ENE, provavelmente transpassando o alto estrutural da margem leste da bacia (Fig. 8).

Intervalo Intermediário $\mathrm{O}$ intervalo intermediário apresenta uma espessura mínima de $60 \mathrm{~m}$, podendo ser subdividido em três associações de fácies: canais fluviais de carga mista, inundações em lençol distal e planície de inundação.

Associação de Fácies 5 - Canais fluviais de carga mista Composta por corpos arenosos em lençol, com espessura entre 1 e $2 \mathrm{~m}$, amalgamados ou separados por camadas tabulares de pelitos vermelhos laminados (Fl) ou maciços (Fm), com 1-2 m de espessura (Fig. 9A). A base dos corpos arenosos é fracamente erosiva, sendo sobreposta por lags de arenitos grossos a médios, maciços (Sm) ou com laminações cruzadas de baixo-ângulo (Sl), contendo seixos e grânulos de quartzo e intraclastos pelíticos (Fig. 9D). Estes lags basais possuem em média $20 \mathrm{~cm}$ de espessura e são sobrepostos por arenitos médios a finos, dispostos em sets de estratificações cruzadas acanaladas (St) (Fig. 9C), compondo ciclos de granodecrescência. As paleocorrentes apresentam alta dispersão, com vetor médio para ENE (Fig. 9B).

INTERPRETAÇÃO Os corpos arenosos com base erosiva são interpretados como depósitos de preenchimento de canais. A ausência de macroformas de acresção lateral indica canais com baixa mobilidade lateral, preenchidos por agradação. Tal imobilidade sugere que o reposicionamento do canal para outras partes da planície de inundação provavelmente ocorreu por eventos de avulsão (e.g. Mack \& Leeder 1998), em detrimento da migração lateral contínua. A pequena incisão observada na base dos corpos arenosos pode estar associada à orientação do afloramento, que é quase paralela ao paleofluxo, fazendo com que se observe o canal 

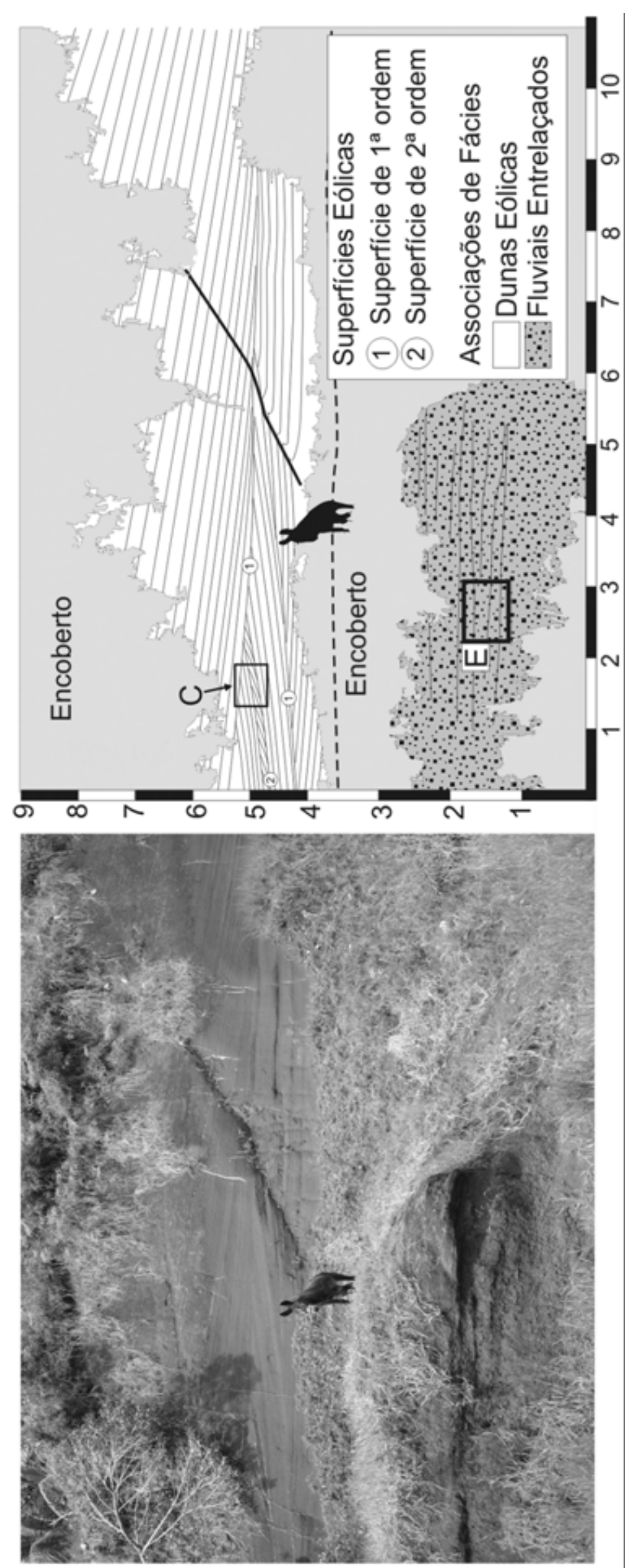

$\varangle$

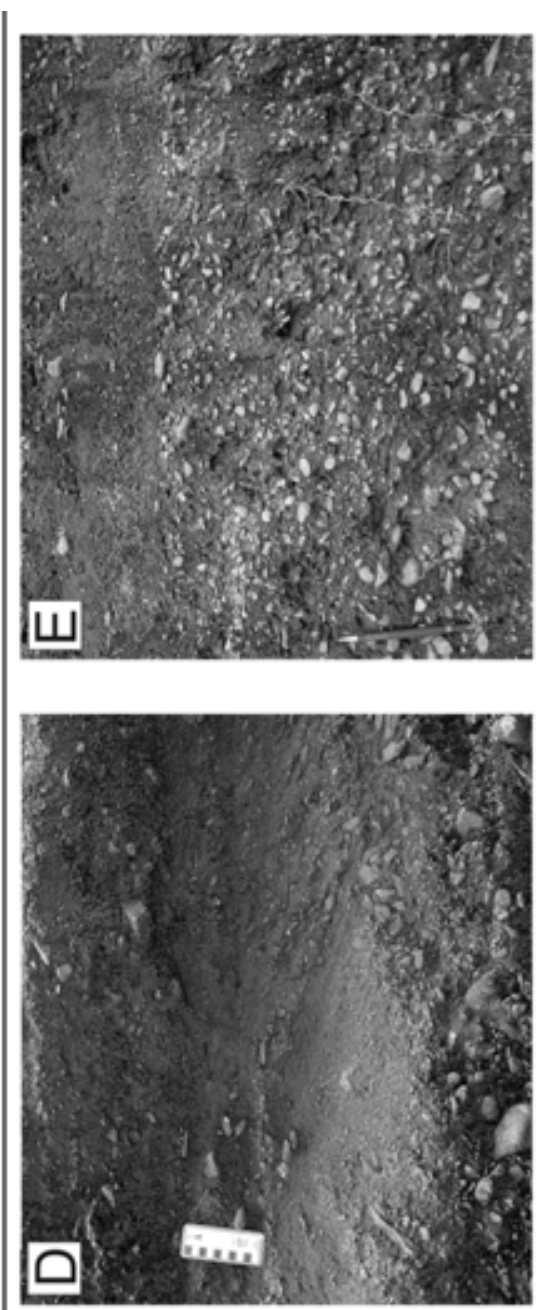

:

ڤ

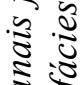

¿

\& $\frac{1}{2}$

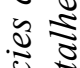

is

$\approx \widehat{ล}$

8 8

:

है

0

융

ธิ ป

ฐ

8

논

象

डิ $\frac{1}{3}$

ช

气ิ

$\div \div$

8

ป

ะ
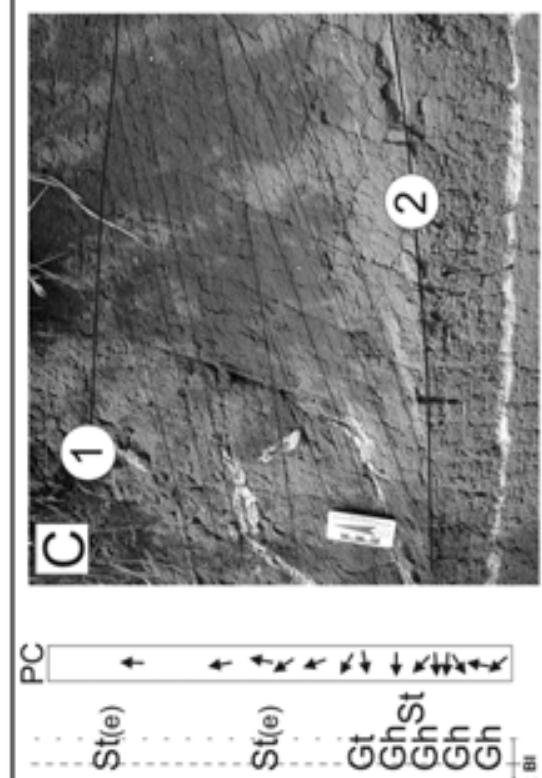

¿

के $\frac{7}{7}$

: ป

ई

$2 \frac{2}{2}$

ป 18

के

8 का

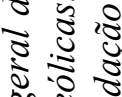

उ

ปิ

ปे

$2 \frac{1}{2}$

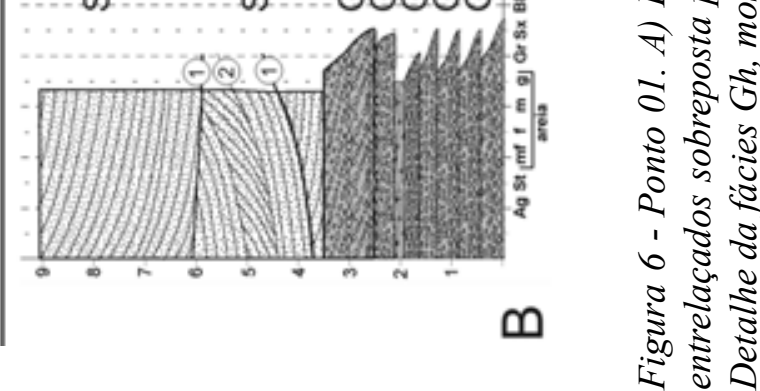




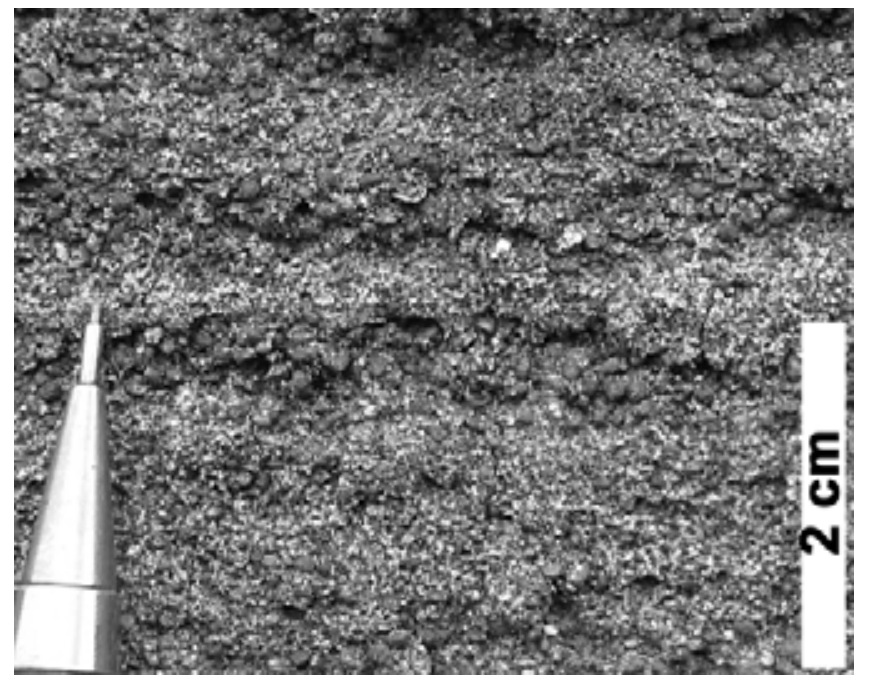

Figura 7 - Arenitos finos a grossos, bimodais apresentando gradação inversa na escala de laminação. Ponto 01 (ver figura 1 para localização).

longitudinalmente, e não transversalmente, como seria ideal. Este fator também pode mascarar a geometria dos corpos arenosos. Os pelitos são interpretados como depósitos de decantação nas regiões externas ao canal durante eventos de inundação e extravasamento. A dispersão nas paleocorrentes sugere canais com moderada sinuosidade ou que se bifurcam.
Associação de Fácies 6 - Inundações em lençol distal Composta por arenitos finos a médios, com espessuras de 1 a $10 \mathrm{~cm}$, com base abrupta não erosiva, intercalados com finas camadas de pelitos ( 0,1 a $5 \mathrm{~cm}$ de espessura). Esta intercalação pode formar corpos heterolíticos tabulares, com até $1 \mathrm{~m}$ de espessura, limitados por camadas tabulares de pelitos laminados (Fl) (Figs. 10A e 10B). Os arenitos geralmente são maciços (Sm) (Fig. 10C) ou apresentam estratificações horizontais (Sh) ou laminações cruzadas de marcas onduladas (Sr). Os pelitos são maciços, avermelhados, por vezes apresentando gretas de contração (Fm) (Fig. 10C). A razão arenito/pelito normalmente varia entre 0,4 e 0,6 , configurando heterolitos com acamadamento do tipo ondulado (Fig. 10C). Em alguns pacotes observa-se uma maior proporção de pelitos, configurando heterolitos com acamadamento do tipo lenticular (Fig. 10D). As paleocorrentes medidas indicam paleofluxo para ENE (Fig. 10B).

INTERPRETAÇÃO Os heterolitos podem ser interpretados como depósitos de inundação em lençol, que podem estar associados a dois contextos deposicionais distintos: (a) extravasamento lateral aos canais durante cheias (extravasamento de crevasses) ou (b) inundações em lençol efêmeras e de alta energia, posicionadas nas porções distais de canais fluviais distributários (Hampton \& Horton 2007, Spalletti \& Piñol 2005). A unidirecionalidade das paleocorrentes e a coincidência do seu vetor médio com o dos depósitos de canais

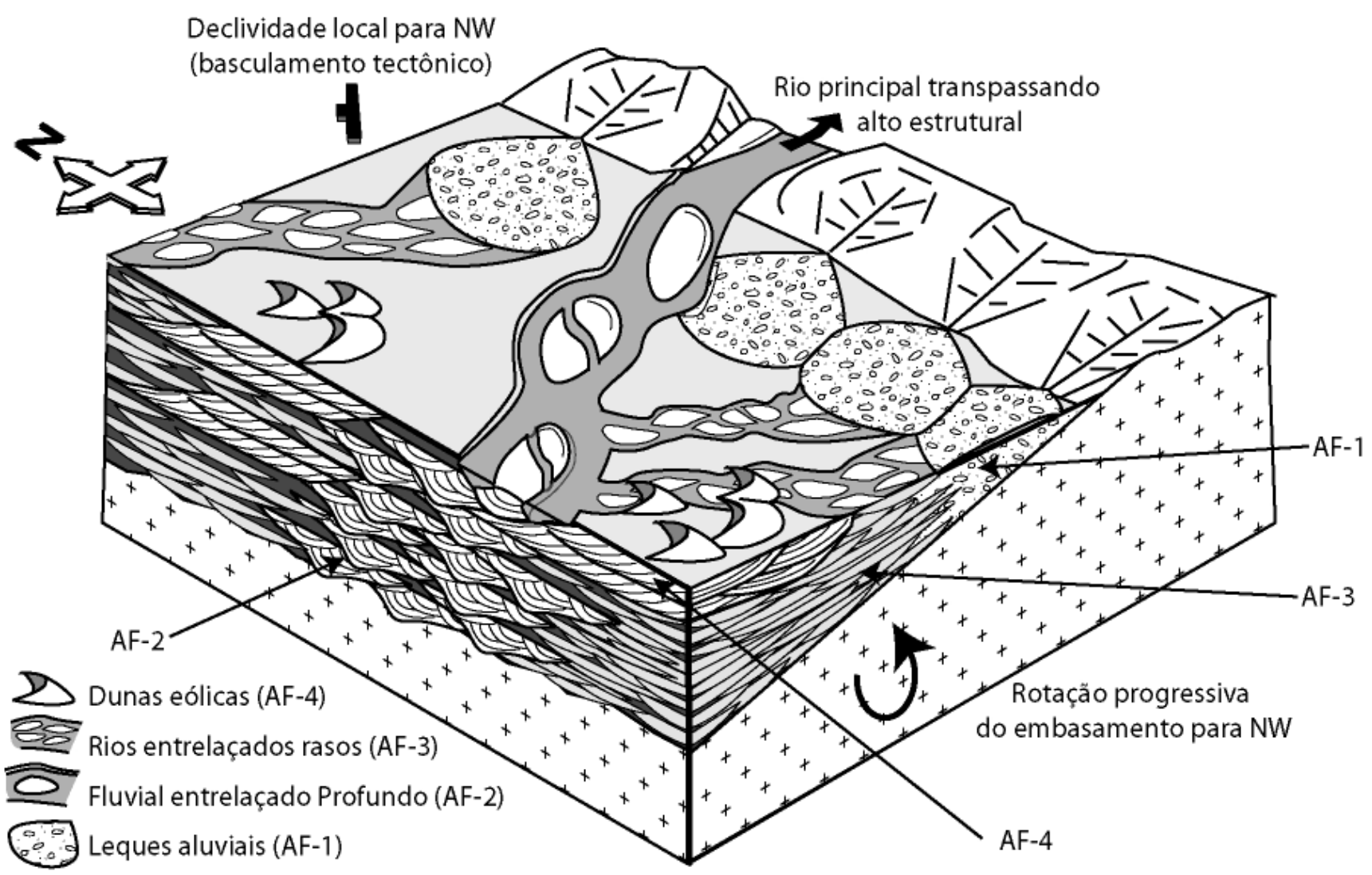

Figura 8 - Diagrama ilustrando a relação entre os sistemas deposicionais do intervalo basal. Sem escala. 

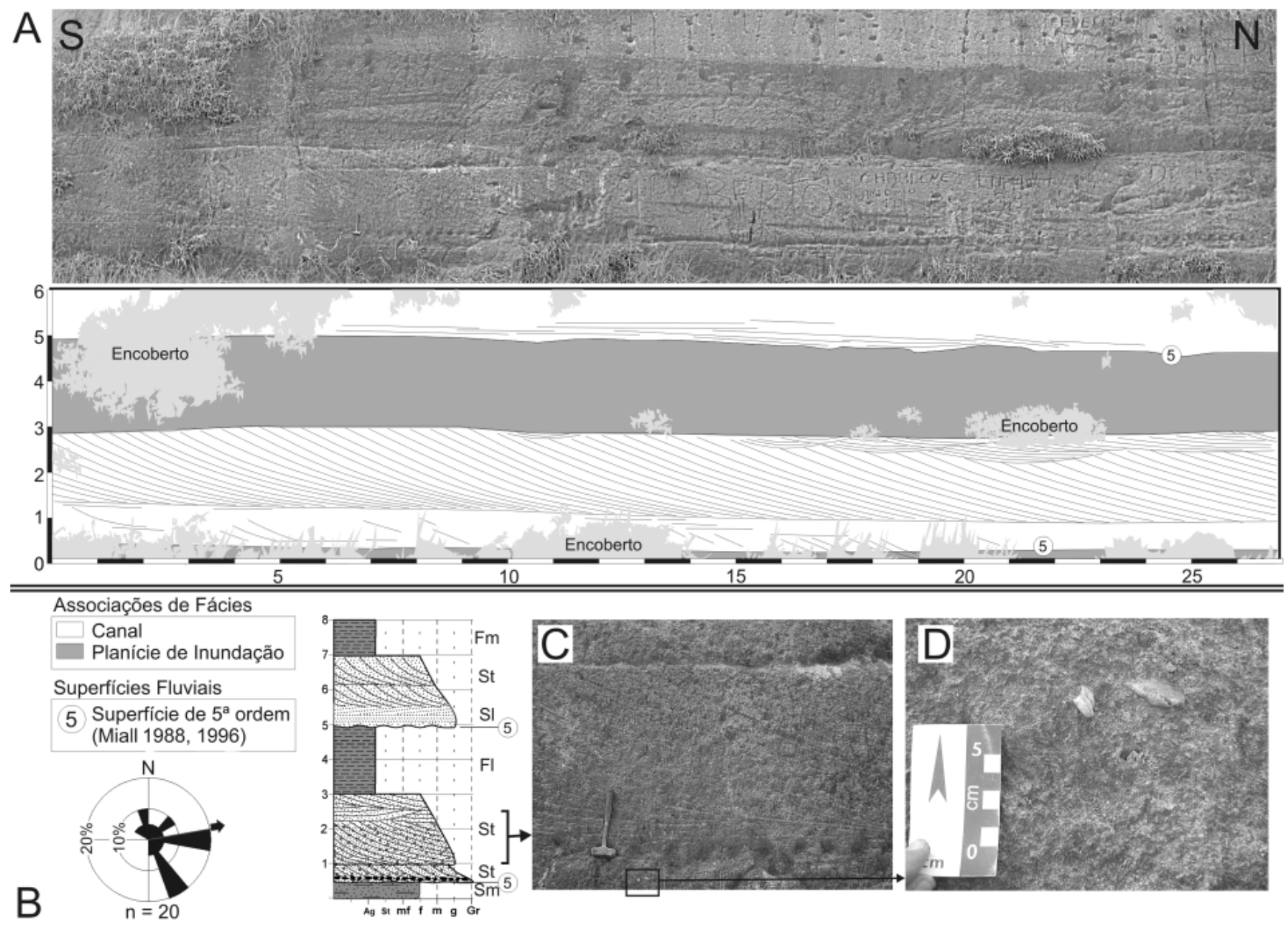

Figura 9 - Ponto 02. A) Fotomosaico do afloramento e sua interpretação mostrando associações de fácies de canais fluviais e planicie de inundação. B) Seção colunar e paleocorrentes. C) Arenitos com cruzadas tangenciais. D) Seixos dispersos na base do ciclo de granodecrescência.

fluviais de carga mista (AF-5) sugerem que esta associação de fácies representa lobos de extravasamento distais de um sistema fluvial distributário ao invés de depósitos de extravasamento de crevasse, que devem apresentar sentidos de paleocorrentes aproximadamente transversais aos eixos dos canais. Os arenitos têm sua gênese vinculada a fluxos hiperconcentrados $(\mathrm{Sm})$ ou fluxos trativos mais diluídos com variações no regime de fluxo de inferior ( $\mathrm{Sr}$ ) até superior (Sh). Os pelitos, por sua vez, devem ter sido depositados por assentamento gravitacional nos estágios finais da inundação. A presença de gretas de contração indica períodos de não deposição e exposição subaérea entre as inundações, sugerindo certo grau de "sazonalidade" fluvial.

Associação de Fácies 7 - Planície de Inundação Composta por (a) ritmitos síltico-argilosos e (b) folhelhos esverdeados $(\mathrm{Fl})$. Os ritmitos formam pacotes com espessuras de 3 a $9 \mathrm{~m}$, compostos por finas lâminas $(0,2-0,5 \mathrm{~cm})$ de argilitos laminados $(\mathrm{Fl})$ ou maciços, raramente gretados (Fm) (Fig. 11A), intercaladas com siltitos arenosos com laminações cruzadas de marcas onduladas de corrente (Sr) (Fig. 11B). Os ritmitos apresentam variações verticais na coloração, alternando níveis de coloração marrom e verde. São observadas escavações cilíndricas verticais, diagonais (Fig. 11C) e horizontais com diâmetros de 2-5 mm e contatos abruptos. Os folhelhos esverdeados compõem camadas tabulares com 1 a $6 \mathrm{~m}$ de espessura, contendo abundantes conchostráceos fósseis. Bioturbação fraca a moderada, por tubos diagonais e verticais é bastante comum. Mais raramente, ocorrem pelitos maciços com textura caracterizada por agregados esferoidais (Fm) (Fig. 11D). Localizadamente, o acamamento encontra-se perturbado por falhas normais (Fig. 12) que são truncadas por depósitos fluviais do intervalo superior.

INTERPRETAÇÃO A abundância de pelitos indica um ambiente de baixa energia com pequenas flutuações na descarga. Os ritmitos sílticos-argilosos foram depositados por decantação em corpos d'água rasos e efêmeros, sujeitos à exposição subaérea, evidenciada pelas gretas de contração. A variação de cores em algumas camadas indica alternância entre condições mais oxidantes e mais redutoras (Retallack 1988). Isto sugere que o nível do freático estava sujeito a flutuações, indicando certo 


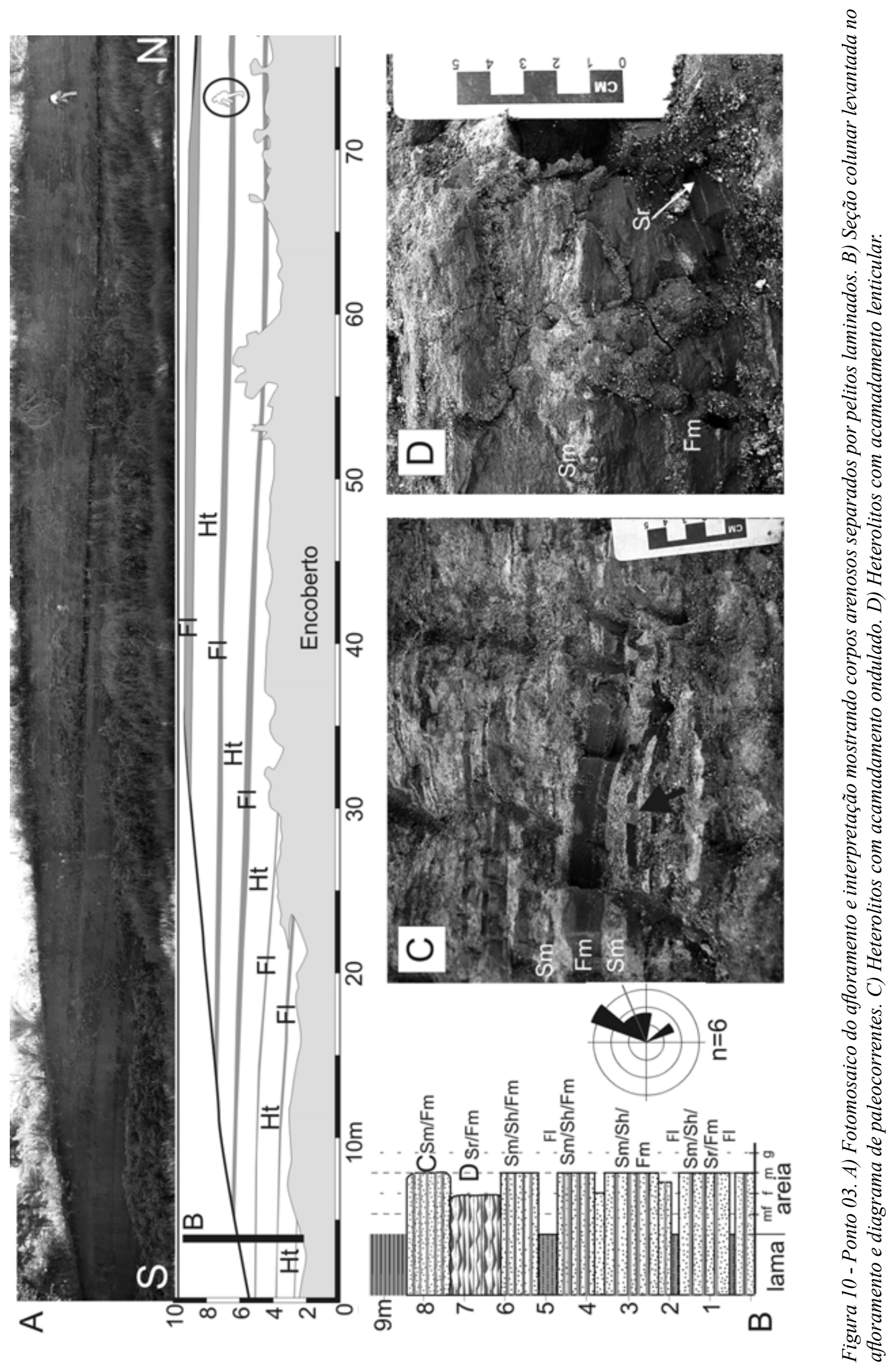



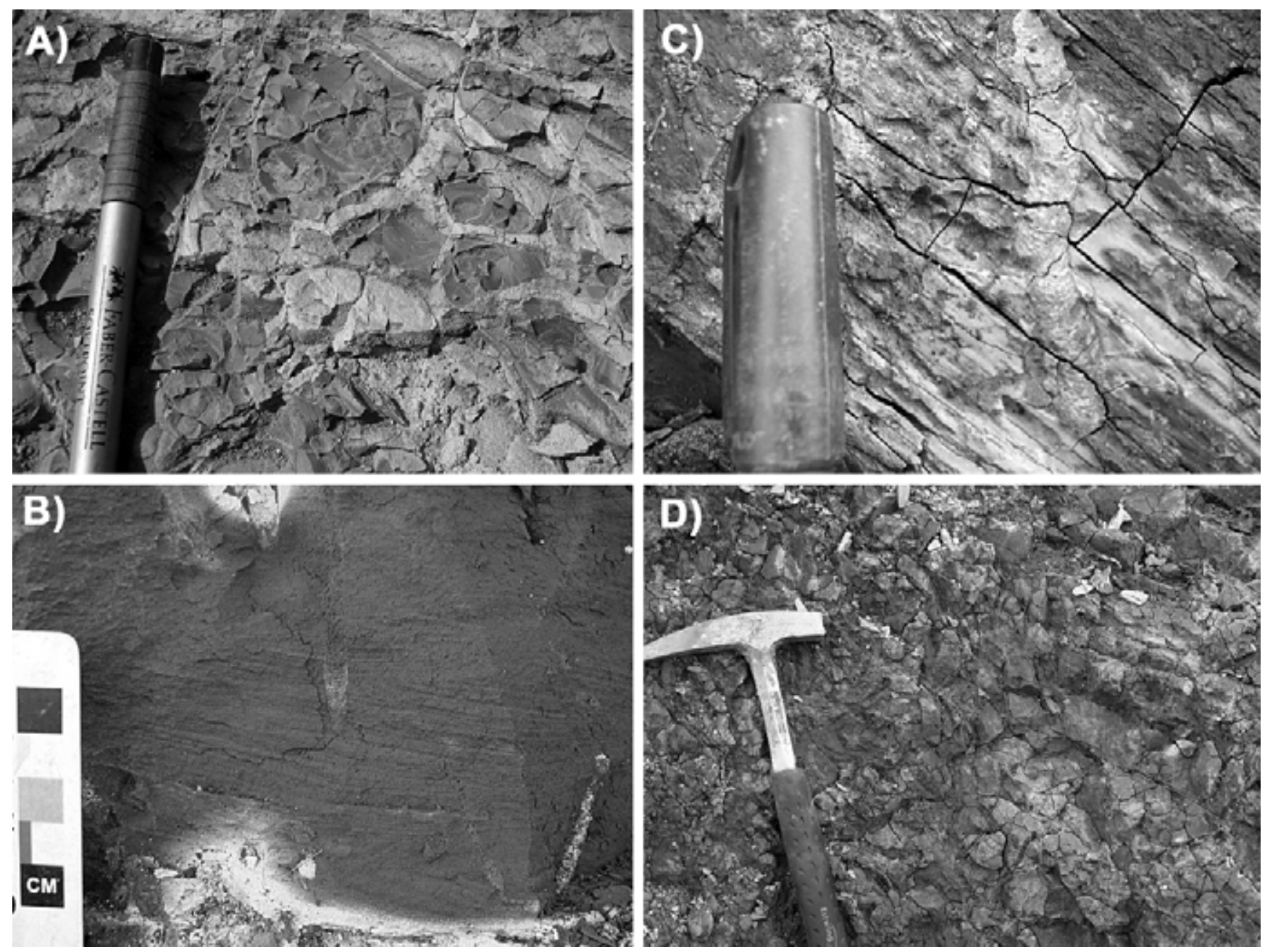

Figura 11 - Ponto 06 (A, C, D) e Ponto 13 (B). A) Pelitos com gretas de contração preenchidas por arenitos finos. B) Siltito arenoso com ripples de corrente. C) Pelito mosqueado com escavação tubular diagonal preenchida por marcas anelares. D) Pelito maciço com agregados esferoidais.

grau de sazonalidade, com solos alagadiços se alternando com solos mais secos (Bouma et al. 1990). A bioturbação com contatos abruptos indica que o substrato escavado pela fauna era firme, provavelmente devido à desidratação pós-deposicional (Fisher et al. 2007). Os pelitos maciços com agregados esferoidais sugerem períodos de não deposição e subsequente oxidação e alteração pedogenética (Retallack 1988). Os pelitos esverdeados, por sua vez, indicam condições redutoras, associadas com períodos de subida do nível freático. A espessura considerável destes depósitos (1 a $6 \mathrm{~m})$ e a ausência de feições indicativas de exposição subaérea sugerem que os lagos podem ter perdurado por períodos relativamente longos.

MODELO DEPOSICIONAL DO INTERVALO INTERMEDIÁRIO A ausência de significativas quebras na sedimentação permite supor que os depósitos fluviais de carga mista, de inundações em lençol distais e lacustres, ocorriam lateralmente justapostos. O modelo deposicional que abrange estas associações de fácies é o sistema fluvial distributário (sensu Nichols \& Fisher 2007). O modelo conceitual deste sistema (Fig. 13) compreende um leque construído pela repetida avulsão de rios efêmeros que apresentam rápida diminuição na descarga em direção à bacia. A zona distal deste sistema é caracterizada ou por leques de espalhamento distais (distal splays) ou por deltas de baixo relevo (durante períodos de lago alto). A zona bacinal se caracteriza ou por uma planície de inundação lamosa ou por lagos rasos.

Neste contexto, os canais fluviais de carga mista (AF-5) representariam a porção intermediária desse sistema, caracterizada por rios de moderada sinuosidade, preenchidos por agradação. Estes rios formam corpos arenosos isolados uns dos outros por extensos depósitos pelíticos da planície de inundação adjacente (Fig. 13). Os depósitos de inundações em lençol distal (AF6) representam os leques de espalhamento na porção distal deste sistema, onde fluxos efêmeros e desconfinados varriam amplas áreas da planície de inundação na zona bacinal (Fig. 13), gerando uma alternância de delgadas camadas de arenitos e pelitos. Esta alternância 


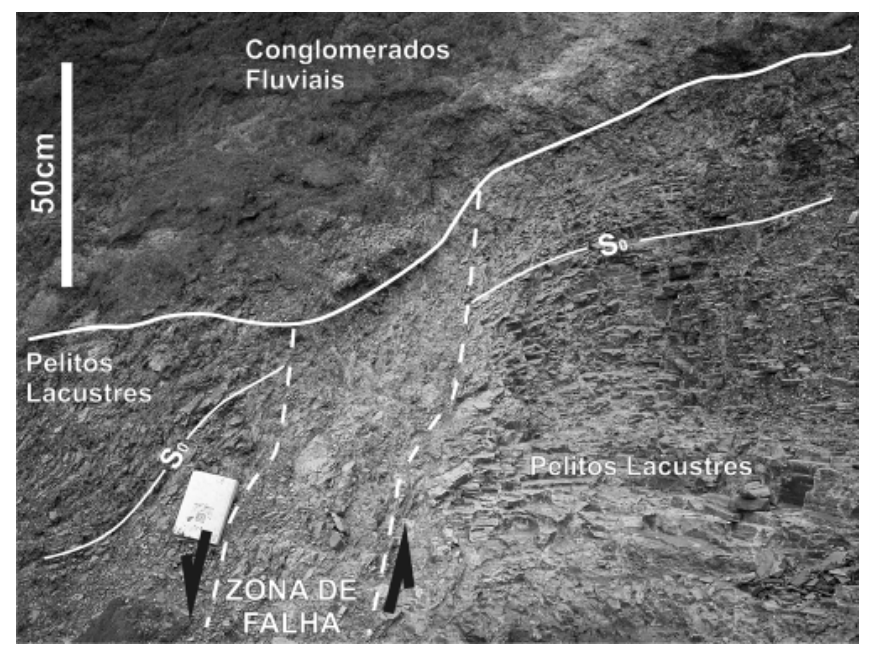

Figura 12 - Pelitos lacustres sobrepostos por conglomerados fluviais. A falha normal sindeposicional que deforma os pelitos é truncada pelos conglomerados.

forma espessos pacotes heterolíticos que se intercalam com camadas mais espessas de pelitos da planície de inundação (AF-7). Isto sugere que esta área era sujeita a variações espaciais (avulsão do canal) e/ou temporais (variações climáticas) no aporte fluvial, o que resultou em mudanças na posição dos leques de espalhamento distais (Fisher et al. 2007). A porção bacinal deste sistema é representada pelos depósitos pelíticos da planície de inundação (AF-7). Esta região era caracterizada pela presença de lagos rasos e poças durante o final das inundações. A presença de gretas de contração, variações na coloração e pelitos pedogenizados indicam que esta região era sujeita a variações sazonais na profundidade dos lagos, com exposição subaérea e formação de solos. $\mathrm{O}$ aporte fluvial nesta região era bastante restrito, sendo marcado por delgadas camadas de siltitos arenosos com ripples de corrente.

Intervalo Superior O intervalo superior apresenta uma espessura mínima de $40 \mathrm{~m}$, podendo ser subdividido em três associações de fácies distintas: canais fluviais de carga de fundo, inundações em lençol intermediárias e dunas eólicas.

Associação de fácies 8 - Canais fluviais de carga de fundo Composta por corpos areno-conglomeráticos em lençol preenchendo amplas depressões (Fig. 14A). Os conglomerados variam de grânulos até blocos, com clastos subangulares a arredondados, compostos por metagranitoides e quartzo de veio. Duas diferentes sucessões de fácies podem ser definidas. A primeira forma ciclos granodecrescentes compostos por conglomerados com estratificações plano-paralelas, (Gh) que gradam para conglomerados com estratificações cruzadas acanaladas incipientes (Gt) (Fig. 14B). A

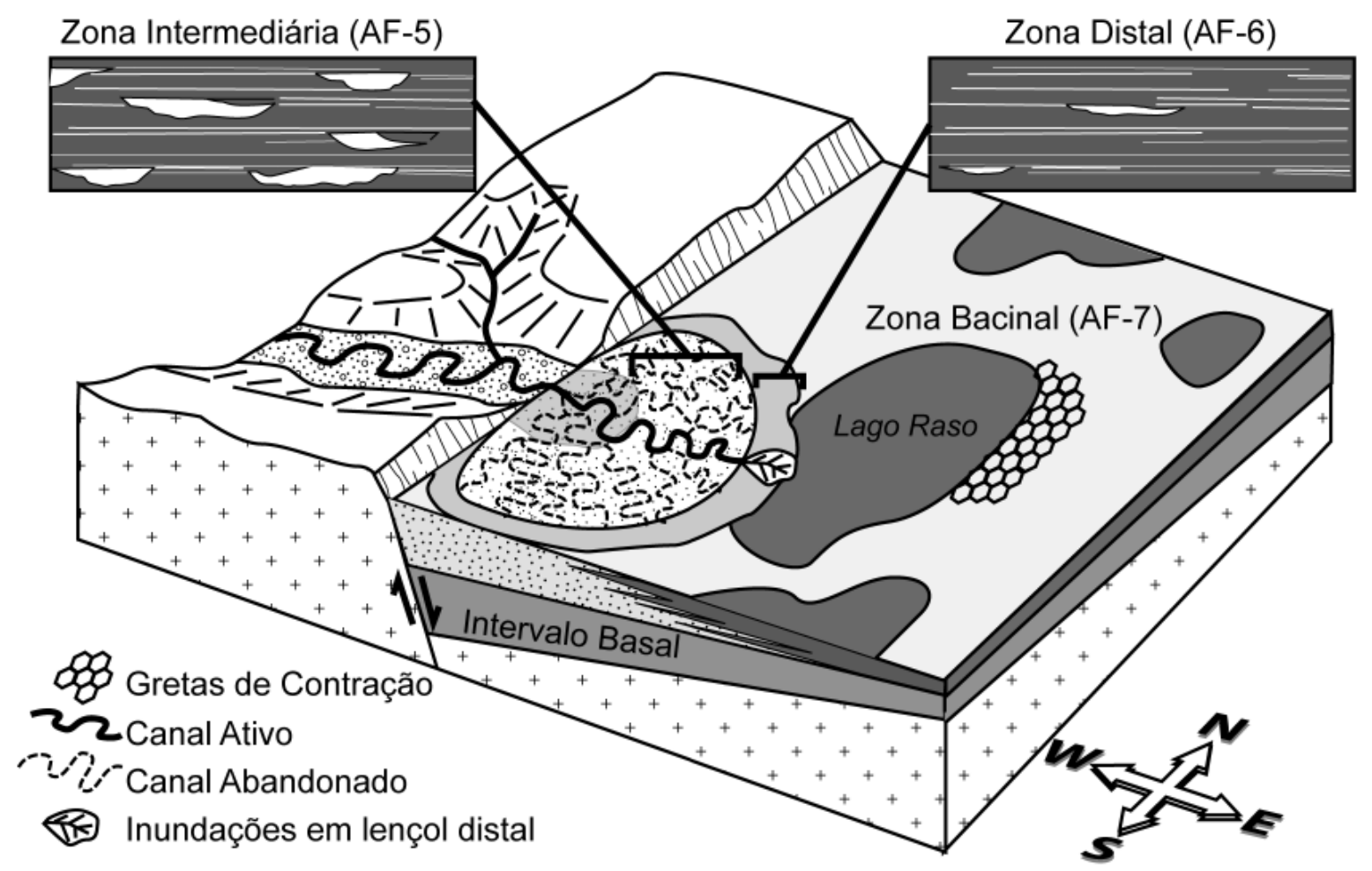

Figura 13 - Modelo deposicional do intervalo intermediário. Sistema fluvial distributário caracterizado por um leque construído pela repetida avulsão do canal principal. No topo, são mostradas as características arquiteturais dos depósitos da zona intermediária e distal. Modificado de Nichols \& Fisher (2007). 

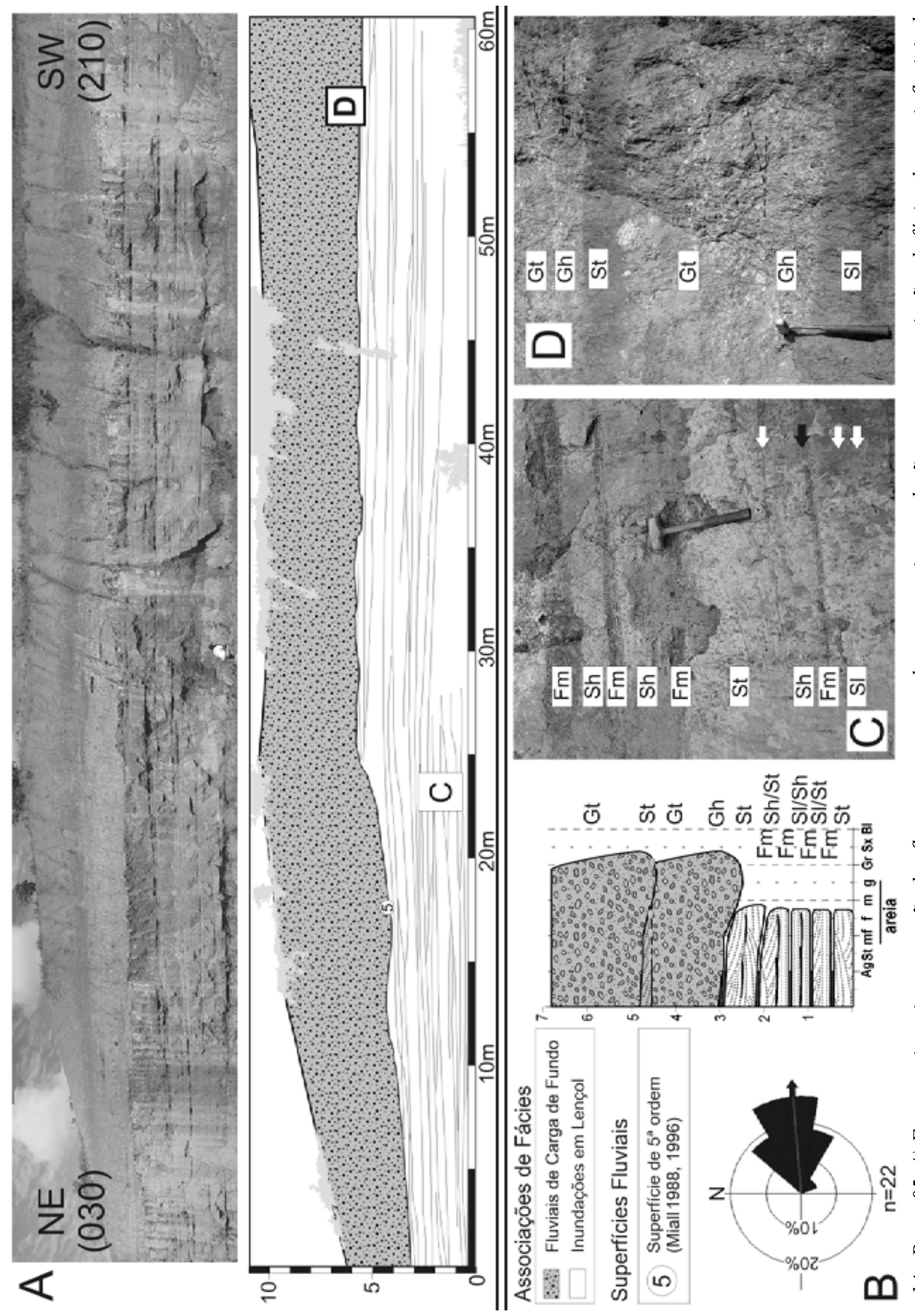

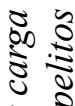

$\approx$

s

紊

竎

¿

(2)

ये क

昰

ช. ข

थै

ن⿺

帘

$\approx$ อ 0

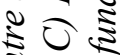

ฮ $a$

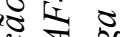

ป

o \& ะ

$0 \stackrel{2}{2} \stackrel{2}{2}$

.

ป

ல $\frac{2}{3}$

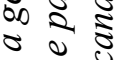

$\therefore \neq$

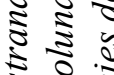

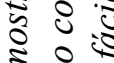

sis 2

요

ई

ธิ

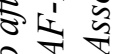

워

워 궁

इ

¿

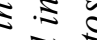

- $0:$

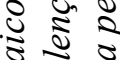

竎

2.

I

$\mathbb{2}$

น.

ㅇ 07

ई के हे

$00 \pi \frac{1}{2}$

- 2

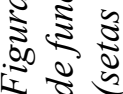


segunda sucessão forma ciclos compostos por conglomerados maciços $(\mathrm{Gm})$ sobrepostos abruptamente por arenitos grossos a conglomeráticos com estratificações plano-paralelas (Sh). Os contatos basais destes ciclos são abruptos não erosivos e suas espessuras variam entre $0,3 \mathrm{~m}$ e $0,5 \mathrm{~m}$. Os dados de paleocorrentes são escassos, porém, as poucas medidas sugerem transporte para ENE e para N. Esta associação de fácies intercala-se com depósitos de inundações em lençol intermediárias (AF-09) (Fig. 14A) ou, mais raramente, dunas eólicas (AF-10).

INTERPRETAÇÃO Os corpos areno-conglomeráticos, caracterizados pelas litofácies Gh, Gt, Gm, St e Sh, preenchendo amplas depressões, representam depósitos de canais fluviais pobremente desenvolvidos. As unidades individuais de preenchimento dos canais registram um transporte de carga de fundo por tração, sob a influência de altas velocidades de descarga (Bridge 2006). Os ciclos internos aos canais marcam variações rítmicas na descarga, provavelmente associadas com descargas efêmeras. A ausência de depósitos da planície de inundação atesta que os canais apresentavam alta mobilidade lateral, retrabalhando os depósitos subjacentes (Mackey \& Bridge 1995, Bridge 2003).

\begin{abstract}
Associação de fácies 9 - Inundações em lençol intermediárias Consiste de corpos arenosos em lençol, com base plana a fracamente erosiva, com $15-40 \mathrm{~cm}$ de espessura e 7-15 m de comprimento (Fig. 14A). Frequentemente apresentam-se verticalmente e lateralmente amalgamados. Os corpos arenosos são capeados de forma abrupta por delgadas camadas ( $1 \mathrm{a} 15 \mathrm{~cm}$ de espessura) de pelitos maciços, por vezes gretados (Fm) (Fig. 14C). A amalgamação lateral e vertical dos lençóis pode gerar unidades arenosas com 0,7-1 $\mathrm{m}$ de espessura e algumas dezenas de metros de comprimento. Quando amalgamados, os corpos arenosos podem ser individualizados pela presença de lâminas pelíticas descontínuas ou níveis com intraclastos pelíticos na base das camadas. Internamente, os corpos são compostos por arenitos arcoseanos médios a grossos, bem selecionados, com laminações horizontais (Sh), estratificações cruzadas de baixo ângulo (Sl) ou, mais raramente, estratificações cruzadas acanaladas (St) (Fig. 14C).
\end{abstract}

INTERPRETAÇÃO A geometria em lençol indica fluxos desconfinados a fracamente canalizados. A abundante presença das litofácies Sh e Sl está associada a inundações de alta energia. Entretanto, a presença da litofácies St indica variações na velocidade do fluxo durante o mesmo evento ou entre eventos distintos. A natureza planar da base de alguns depósitos sugere que o substrato era relativamente competente, sendo possivelmente estabilizado pela vegetação ou endurecido por longos períodos de exposição subaérea (Fisher et al. 2007). O grande número de depósitos individuais que se amálgamam indica a deposição por múltiplos eventos de inundação.
A lama que capeia abruptamente os depósitos indica rápida desaceleração do fluxo no final da inundação (e.g. Tunbridge 1981, Rhee \& Chough 1993). O caráter maciço, as escavações, e a presença de gretas, sugerem uma planície de inundação bem drenada, com exposição subaérea (Deluca \& Eriksson 1989, McCarthy et al. 1997).

Associação de Fácies 10 - Dunas Eólicas Composta por arenitos bimodais, finos a médios, arranjados em sets com estratificações cruzadas tangenciais, de 1 a $1,5 \mathrm{~m}$ de espessura, separados por superfícies planas. Internamente, os sets são compostos por lâminas demarcas onduladas eólicas, milimétricas e inversamente gradadas (Fig. 15). Os estratos cruzados apresentam um mergulho principal para NW (Fig. 6A).

INTERPRETAÇÃO Os arenitos bimodais, com sets de estratos cruzados de grande porte, sugerem que esta associação de fácies representa depósitos residuais de dunas eólicas. A presença de estratos cruzados formados exclusivamente por laminações de eólicas indica dunas sem a face de escorregamento bem desenvolvida ou severamente truncada (Kocurek 1996, Scherer 2000). O sentido unimodal das paleocorrentes sugere dunas crescentes.

MODELO DEPOSICIONAL DO INTERVALO SUPERIOR As associações de fácies que compõem este intervalo são interpretadas como pertencendo à zona proximal de um sistema fluvial distributário (Fig. 16), caracterizada por canais fluviais multiepisódicos dominados por processos trativos de alta energia. $\mathrm{O}$ alto grau de amalgamação dos corpos arenosos pode ser atribuído a repetidas avulsões dos canais em um contexto de baixa taxa de criação de espaço de acomodação. A

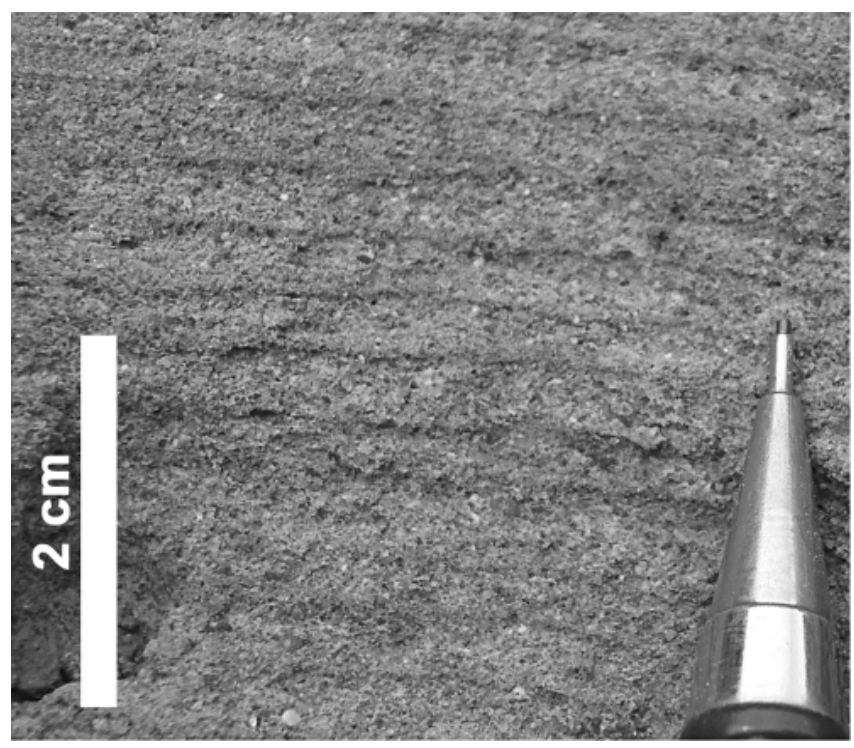

Figura 15 - Arenitos finos a médios, bimodais apresentando gradação inversa na escala de laminação. Ponto 12 (ver figura 1 para localização). 


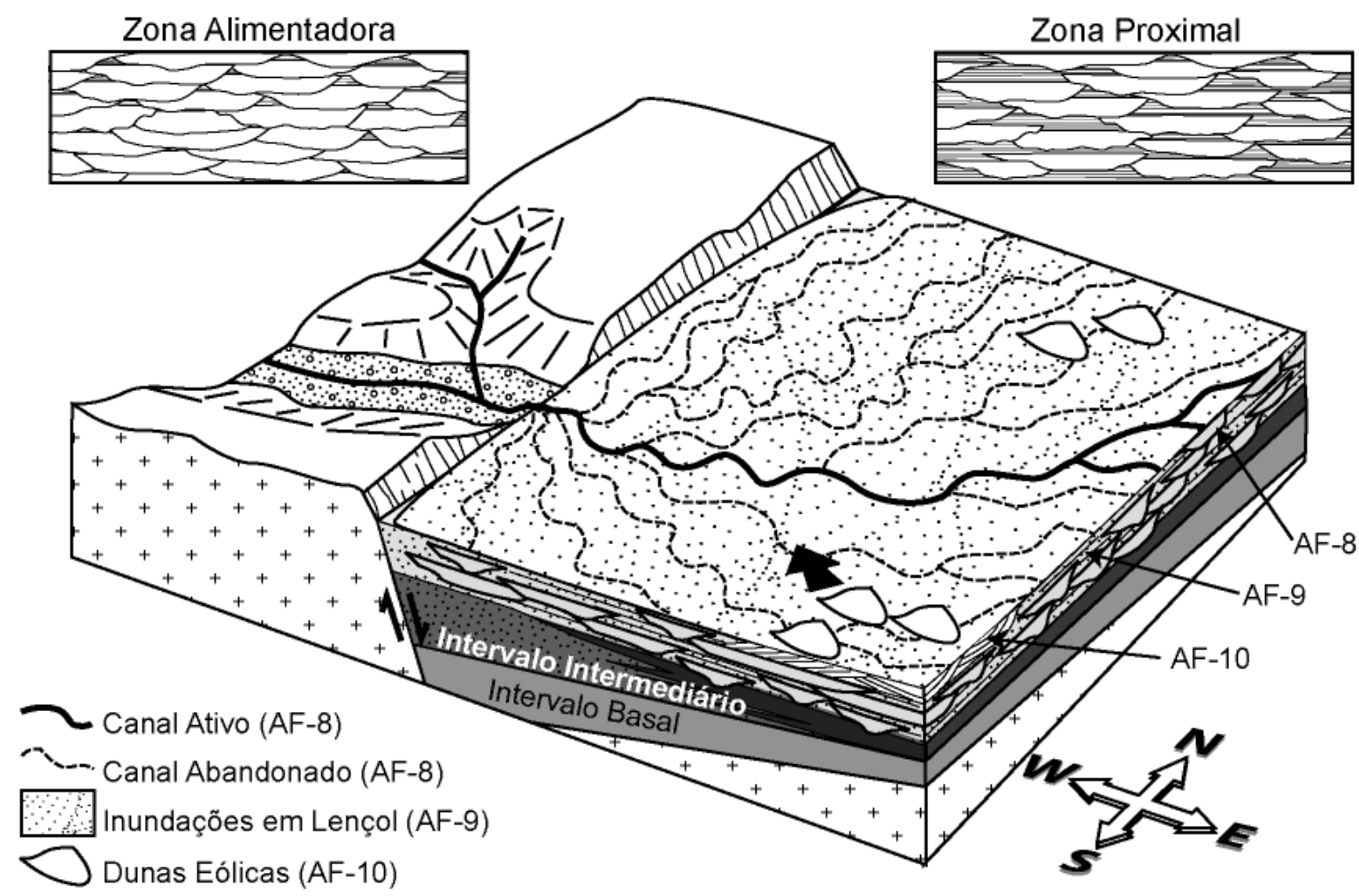

Figura 16 - Modelo deposicional do intervalo superior: porção proximal de um sistema fluvial distributário, com as características arquiteturais dos depósitos das zonas alimentadora e proximal, modificadas de Nichols \& Fisher (2007).

elevada frequência das avulsões pode ser atribuída à alta razão carga de fundo/descarga e à ausência de sedimentos finos coesivos nas porções externas aos canais (Hassan 2005). Os depósitos de inundações em lençol (AF-9) são gerados pela dispersão de fluxos de água associada à formação de lobos de extravasamento nas porções terminais de canais fluviais distributários (terminal splays) ou quando os canais são totalmente preenchidos por agradação. Os depósitos de dunas eólicas (AF-10) representam períodos de inatividade fluvial e retrabalhamento dos sedimentos pelo vento.

IDADE A idade dos sedimentos foi identificada com base em fósseis de conchostráceos presentes nos folhelhos da associação de fácies de planície de inundação (AF-7). Estes conchostráceos estão preservados na forma de impressões na rocha e ocorrem ora amontoados em grande quantidade, ora dispersos. Frequentemente estão bem preservados, porém, em alguns casos, ocorrem bastante fragmentados.

Foi possível identificar dois Gêneros: Cyzicus e Estheriina. O primeiro é representado pelas espécies: pricei, mawsoni e brauni, já o segundo é representado pela espécie astartoide (Fig. 17). Ambos os gêneros já foram identificados na Bacia de Camamu-Almada por Carvalho (1993) e Rohn \& Cavalheiro (1996).

Em relação à idade, Carvalho (1993) observa que a espécie Cyzicus pricei é bastante comum em rochas neocomianas das bacias interiores do nordeste brasileiro, tendo uma considerável redução no Barremiano e restringindo-se no Aptiano-Albiano. De acordo com Rohn \& Cavalheiro (1996) e Gallego \& Martins-Neto (2006) os espécimes indicariam, para o sedimento, uma idade entres os andares Rio da Serra e Aratu.

\section{EVOLUÇ̃̃O TECTONO-ESTRATIGRÁFICA DO GRÁBEN DE CAMAMU - DISCUSSÃO Diversos} fatores permitem supor que a acumulação sedimentar no Gráben de Camamu foi controlada por tectônica extensional, entre os quais se pode citar: (1) O Andar Rio da Serra, idade dos sedimentos, é caracterizado por sedimentação sin-rifte em diversas bacias brasileiras; (2) os conglomerados depositados por fluxos gravitacionais indicam a presença de altos estruturais locais, provavelmente controlados por falhas normais; (3) o espessamento destes depósitos para NW e a diminuição no basculamento das camadas para o topo da seção parecem ser controlados pela rotação do embasamento; e (4) os depósitos da planície de inundação (AF-7) apresentam falhas normais sin-sedimentares. Portanto, assume-se que as variações na taxa de criação de espaço de acomodação têm um controle dominantemente tectônico.

Em sucessões fluviais desvinculadas da linha de costa, os limites de sequências e as variações de estilos deposicionais podem ser interpretados como resultantes de variações na taxa de criação ou destruição do espaço de acomodação. Fundamentados neste argumento, Martinsen et al. (1999) propuseram uma 

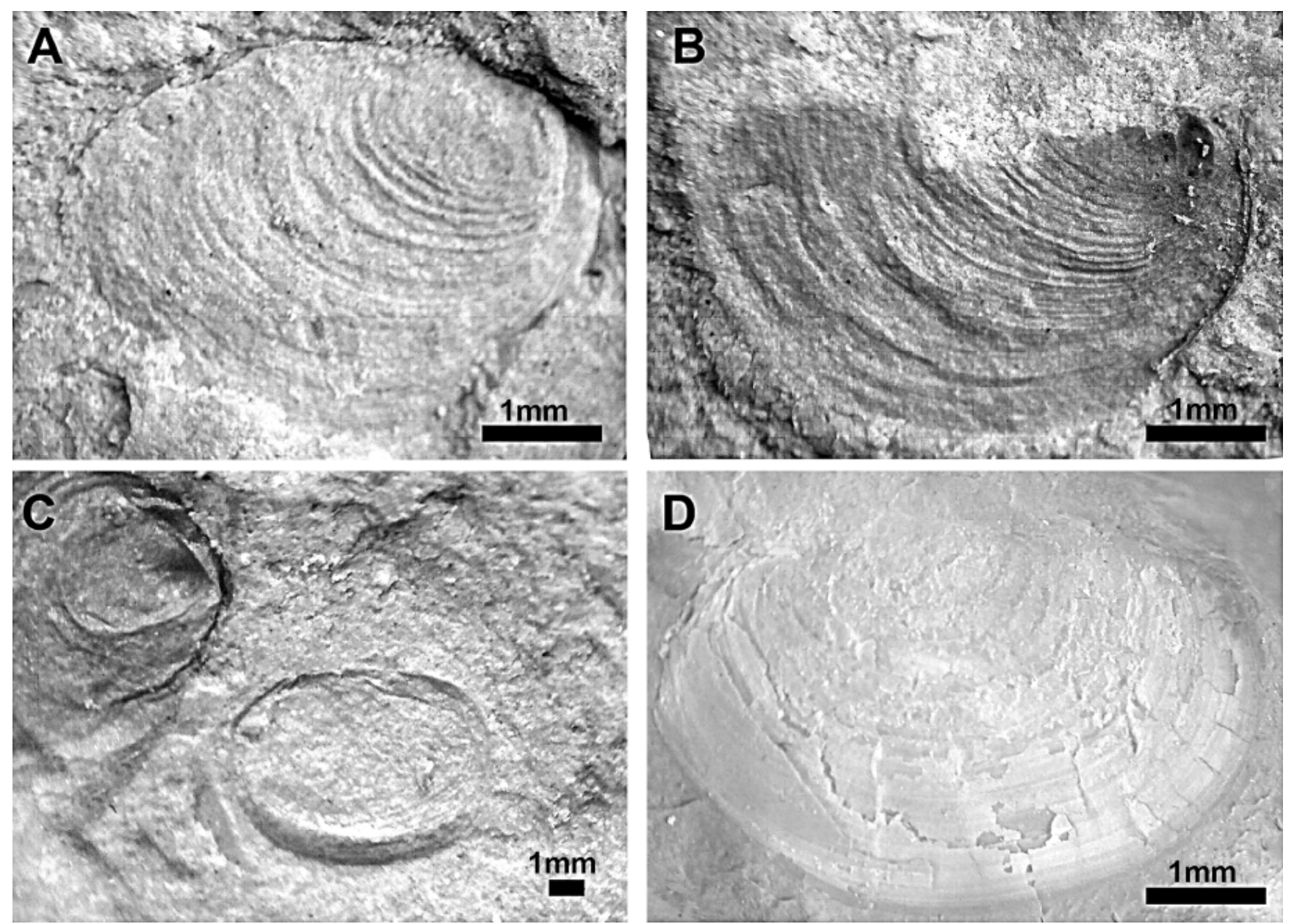

Figura 17 - Conchostráceos identificados nos sedimentos lacustres. A) Cyzicus pricei B) Cizycus mawsoni. C) Cizycus brauni. D) Estheriina astartoides.

subdivisão simplificada para depósitos fluviais baseada em variações no estilo fluvial e na identificação de superfícies estratigráficas regionais. Esta divisão prevê apenas dois tratos de sistemas: trato de baixa taxa de acomodação e trato de alta taxa de acomodação. $\mathrm{O}$ trato de baixa taxa de acomodação é representado por canais fluviais em lençol, multiepisódicos, amalgamados e com raros depósitos de planície de inundação. $\mathrm{O}$ trato de alta taxa de acomodação é caracterizado por canais fluviais isolados, associados com significativos depósitos pelíticos intercanais.

A seção sedimentar preservada no Gráben de Camamu pode ser dividida em duas sequências deposicionais limitadas por discordância. A Sequência I é composta pelos intervalos basal e intermediário, enquanto que a Sequência II é equivalente ao intervalo superior.

O trato de sistemas de baixa taxa de acomodação é representado pelo intervalo basal, caracterizado pelo empilhamento agradacional de leques aluviais e sistemas fluviais entrelaçados, com dunas eólicas subordinadas. As movimentações na Falha de Igrapiúna (falha de borda oeste) rotacionavam o embasamento para NW, formando lentamente uma rampa na margem leste. Esta rampa servia como área-fonte dos leques aluviais (AF-1) e controlava a rede canais entrelaçados rasos (AF-3). Já o sistema fluvial entrelaçado profundo (AF-2) possivelmente transpassava esta rampa. Este sistema fluía para ENE e pode ter sido condicionado pela rede de drenagens preexistente (pré-rifte) que, segundo dados apresentados para depósitos da Formação Sergi na Bacia de Camamu por Born et al. (2008), também fluíam para NE.

$\mathrm{O}$ fato de este sistema transpassar a margens do gráben provavelmente está relacionado com a presença de uma calha tectônica topograficamente mais baixa, localizada a leste do Gráben de Camamu (Fig. 18A). Diversas calhas podem ser observadas claramente no mapa de anomalia Bouguer (Fig. 2).

O estabelecimento de sistemas fluviais distributários do Intervalo Intermediário marca o início do trato de sistemas da alta taxa de acomodação. Este sistema é representado pelos depósitos de canais fluviais de carga mista (AF-5), de inundações em lençóis distais (AF-6) e de planície de inundação (AF-7), empilhados em padrão retrogradacional. Segundo Nichols \& Fisher (2007), o desenvolvimento de sistemas distributários é facilitado pela alta subsidência e pela presença de um alto estrutural elevado na margem da bacia, que evita o desenvolvimento de drenagens externas. Durante este estágio, postula-se, então, que a drenagem transversal principal, que antes atravessava o gráben, passa a ser 
capturada por ele. O Gráben de Camamu se torna então uma bacia fechada, isto é, com a drenagem barrada por uma barreira efetiva (Alto de Camamu) (Fig. 18B). O padrão retrogradacional observado pode estar associado a um incremento na subsidência tectônica que, segundo Gupta et al. (1998), se dá pela propagação lateral e conexão dos segmentos melhor posicionados (Fig. 18B).

O início da Sequência II é caracterizado pela erosão generalizada dos depósitos pelíticos da planície de inundação. Esta erosão é fruto de um rebaixamento no nível de base (perfil de equilíbrio fluvial), cuja origem é difícil de ser determinada, podendo ter um controle climático (aumento da descarga aluvial) ou tectônico (soerguimento da área fonte ou migração de depocentro). Sobre a discordância se estabelece um sistema fluvial distributário proximal composto por canais de carga de fundo (AF-8), inundações em lençol intermediárias (AF-9) e por dunas eólicas subordinadas (AF-10). Essa nova configuração marca o rápido avanço do sistema fluvial distributário, em direção à zona bacinal, e a deposição em um contexto de baixas taxas de criação de espaço.

O truncamento das falhas sin-sedimentares dos depósitos da zona bacinal pela discordância da base da Sequência II (Fig. 12) fortalece a hipótese de origem tectônica para este limite de Sequência. A figura 19C ilustra uma das hipóteses para explicar a geração desta discordância e o subsequente avanço do sistema distributário. Esta hipótese baseia-se no rebaixamento do nível de base regional induzido pela formação de uma ampla e profunda calha a leste do Gráben de Camamu. Este rebaixamento do nível de base seria seguido pelo reajuste do freático em condições de baixas taxas de criação de espaço de acomodação, resultantes da diminuição da atividade tectônica no sistema de falhas de Maragogipe, dado pela migração dos esforços para zonas de falha mais bem desenvolvidas a leste (Fig. 18C).

CONCLUSÕES O Gráben de Camamu representa a porção extremo sul de um sistema de grábens conectados, controlado pelo sistema de Falhas de Maragogipe. Este gráben foi preenchido durante o Andar Rio da Serra por uma sucessão continental controlada por tectônica rifte. Dentro desta sucessão foram individualizadas três unidades informais: (i) intervalo basal; (ii) intervalo intermediário e (iii) intervalo superior, cada uma caracterizada por associações de fácies distintas. Estes intervalos compõem duas sequências deposicionais limitadas por discordância. A Sequência I inclui os intervalos basal e intermediário, enquanto que a Sequência II corresponde ao intervalo superior.

A porção basal da Sequência I (intervalo basal) é composta por leques aluviais provenientes da margem leste. Estes leques são sobrepostos por um sistema de canais entrelaçados profundos, provenientes da margem oeste. Também faz parte deste intervalo um sistema de canais entrelaçados rasos associado com dunas eólicas. O padrão de empilhamento agradacional e a arquitetura fluvial são reflexos das baixas taxas de criação de espaço de acomodação.
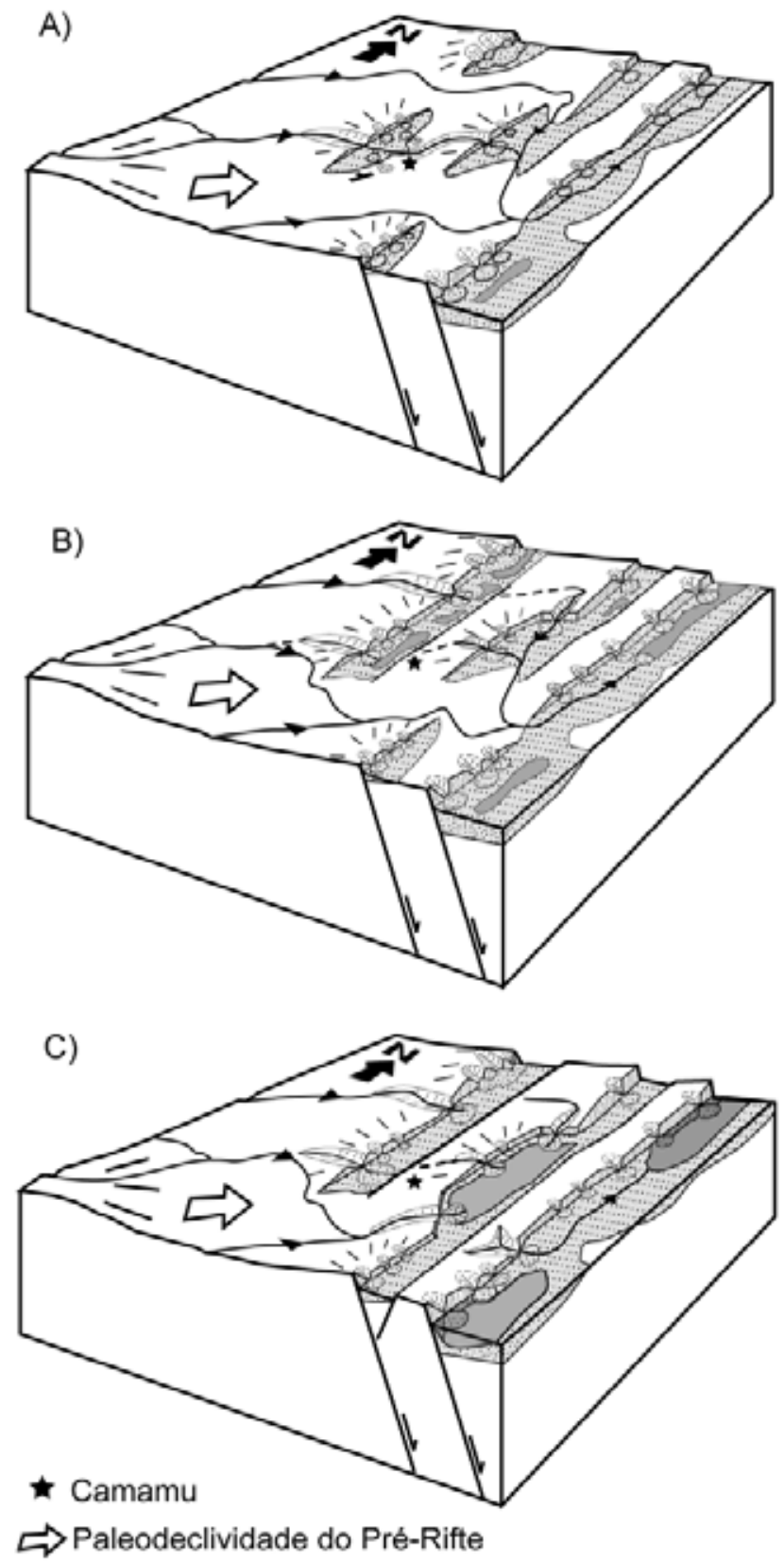

Figura 18 - A) Situação tectônica hipotetizada para o intervalo basal, onde as drenagens antecedentes transpassam os depocentros cortando os footwalls em soerguimento. B) Situação tectônica hipotetizada para o intervalo intermediário. A conexão das falhas aumenta a taxa de subsidência e os altos barram as drenagens. C) Situação tectônica hipotetizada para o intervalo superior, onde o desenvolvimento das calhas, mais a leste, faz com que o Gráben de Camamu tenha a sua taxa de subsidência reduzida.

A porção superior da Sequência I (intervalo intermediário) é composta por canais fluviais de carga mista, sucedidos por depósitos de inundações em lençol distal e por depósitos finos de planície de inundação. Estas associações de fácies caracterizam um sistema fluvial distributário proveniente da margem oeste 
do gráben. $\mathrm{O}$ padrão de empilhamento retrogradacional, característico deste intervalo. configura um trato de sistemas de alta taxa de acomodação.

A Sequência II (intervalo superior) assenta-se sobre uma discordância erosiva e marca uma mudança abrupta de fácies. Os depósitos característicos desta sequência são canais fluviais de carga de fundo, inundações em lençol intermediárias e dunas eólicas. Estes depósitos representam a rápida progradação do sistema distributário em contexto de baixas taxas de criação de espaço de acomodação, logo após uma queda repentina no nível de base.
Trabalhos anteriores, baseados em observações pontuais e correlações litoestratigráficas, haviam associado os depósitos do Gráben de Camamu ao Grupo Brotas, acumulado em contexto pré-rifte. Entretanto, conforme demonstrado no presente trabalho, os depósitos aflorantes no Gráben de Camamu pertencem ao Grupo Almada, correspondendo à sedimentação sin-rifte da Bacia de Camamu.

Agradecimentos À PETROBRAS e à ANP pelo financiamento deste projeto.

\section{Referências}

Asmus H.E. \& Porto R. 1980. Diferenças nos estágios iniciais da evolução da margem continental brasileira: possíveis causas e implicações. In: SBG, Congresso Brasileiro de Geologia, 31, Anais, p. 225-239.

Born C.C., Scherer C.M.S., Adegas F., Casagrande J. 2008. Análise faciológica e arcabouço estratigráfico da Fm. Sergi no norte da Bacia de Camamu, estudo com base em afloramentos da região de Guaibim (Valença). In: SBG, Congresso Brasileiro de Geologia, 44, Anais, p. 144.

Bouma J., Fox C.A., Miedema K. 1990. Micromorphology of hydromorphic soils: applications for soil genesis and land evaluation. In: Bridge J.S. (ed.) Rivers and Floodplains: Forms, Processes, and Sedimentary Record. Oxford, Blackwell, $491 \mathrm{p}$.

Bridge J.S. (ed.) 2003. Rivers and Floodplains: Forms, Processes, and Sedimentary Record. Oxford, Blackwell Science Ltd, $491 \mathrm{p}$.

Bridge J.S. 2006. Fluvial facies models: recent developments. In: Posamentier H.W. \& Walker R.G (eds.) Facies Models Revisited. Tulsa, SEPM Spec. Publ. 84, p. 85-70.

Brookfield M.E. 1984. Aeolian Sands. In: Walker R.G. (ed.) Facies Models. Halmilton, Geoscience Canada Reprint Series, p. 91-103.

Caixeta J.M., Milhomem O.S., Witzke R.E., Dupuy I.S.S. Gontijo G.A. 2007. Bacia de Camamu. B. Geoci. Petrobras, 15(2):455-461.

Carvalho I.S. 1993. Os conchostráceos fósseis das Bacias interiores do Nordeste do Brasil. Tese de Doutorado, Instituto de Geociências, Universidade Federal do Rio de Janeiro, Rio de Janeiro, 319 p.

CBPM - Companhia Baiana de Pesquisa Mineral 2006. Projeto Costa do Dendê: Avaliação da Potencialidade Mineral e Subsidios Ambientais para o Desenvolvimento Sustentado dos Municípios da Costa do Dendê. Landim J.M.D \& Gomes L.C.C (orgs.). Salvador, CBPM, Relatório Técnico, $131 \mathrm{p}$.

Deluca J.L. \& Eriksson K.A. 1989. Controls on synchronous ephemeral- and perennial-river sedimentation in the middle sandstone members of the Triassic Chinle Formations, northeastern New Mexico, USA. Sedimentary Geology, 61:155-175.

Fisher J.A., Nichols G.J., Waltham D.A. 2007. Unconfined flow deposits in distal sectors of fluvial distributary systems: Examples from the Miocene Luna and Huesca
Systems, northern Spain. Sedimentary Geology, 195:55-73.

Gallego O.F. \& Martins-Neto R.G. 2006. The Brazilian Mesozoic Conchostracan Faunas: Its Geological History as an Alternative Tool for Stratigraphic Correlations. Geociências, 25(2):231-239.

Gupta S., Cowie P.A., Dawers N.H., Underhill J.R. 1998. A mechanism to explain rift-basin subsidence and stratigraphic patters through fault-array evolution. Geology, 7:595-598.

Hampton B.A. and Horton B.K. 2007. Sheetflow fluvial processes in a rapidly subsiding basin, Altiplano plateau, Bolivia. Sedimentology, 54(5):1121-1148.

Hassan M.A. 2005. Gravel bar characteristics in arid ephemeral streams. J. Sed. Res. 75:29-42.

Kocurek G. 1996. Desert aeolian systems. In: Reading H.G. (ed.) Sedimentary Environments: Processes, Facies and Stratigraphy. 3.ed., London, Blackwell Science, p. 125153.

Mack G.H. \& Leeder M.R. 1998. Channel shifting of the Rio Grande, southern Rio Grande rift: implications for alluvial stratigraphic models. Sedimentary Geology, 117:207-219.

Mackey S.D. \& Bridge J.S. 1995. Three-dimensional model of alluvial stratigraphy: theory and application. Journal of Sedimentary Research, 65(1):7-31.

Martinsen O.J., Ryseth A., Halland-Hansen W., Fleshe H. Torkildsen G., Idil S. 1999. Stratigraphic base level and fluvial architecture: Ericson Sandsote (Campanian), Rock Springs Uplift, SW Wyoming, USA. Sedimentology, 46:235-259.

McCarthy P.J., Martini I.P., Leckie D.A. 1997. Anatomy and evolution of a Lower Cretaceous alluvial plain: sedimentology and paleosols in the upper Blairmore Group, south-western Alberta, Canada. Sedimentology 44:197- 220.

Miall A.D. 1988. Facies architecture in clastic sedimentary basins. In: Kleinspehn K.L. \& Paola C (eds.) New perspectives in basin analisys. Berlin, Springer-Verlag, p. 67-81.

Miall A.D. (ed.) 1996. The Geology of Fluvial Deposits: Sedimentary Facies, Basin Analysis and Petroleum Geology. New York, Springer-Verlag, 581 p.

Nichols G.J \& Fisher J.A. 2007. Processes, facies and architecture of fluvial distributary system deposits. Sedimentary Geology, 195:75-90. 
Rhee C.W. \& Chough S.K. 1993. The Cretaceous Pyonghae sequence, southeast Korea: terminal fan facies. Palaeogeogr. Palaeoclimatol. Palaeoecol., 105:139-156.

Retallack G.J. 1988. Field recognition of paleosols. In: Reinhardt J. \& Sigleo W.R. (eds.) Paleosols and Weathering Through Geologic Time: Principals and Applications. Boulder, GSA Special Publication 216, p. 1-20.

Rohn R. \& Cavalheiro M.C.T. 1996. Conchostráceos cretácicos da Bacia de Tucano (Bahia) e avaliação do potencial cronoestratigráfico destes crustáceos no Mesozóico do Brasil. In: UNESP, Simp. sobre o Cretáceo do Brasil, 4, Boletim, p. 157-167.

Scherer C.M.S. 2000. Aeolian dunes of the Botucatu Formation (Cretaceous) in Southernmost Brazil: morphology and origin. Sedimentary Geology. 137:63-84
Spalletti L.A. \& Piñol F.C. 2005. From Alluvial Fan to Playa: An Upper Jurassic Ephemeral Fluvial System, Neuquén Basin, Argentina. Gondwana Research, 8(3):363-383.

Siegenthaler C. \& Huggenberger P. 1993. Pleistocene Rhine gravel: deposits of a braided river system with dominant pool preservation. In: Best J.L. \& Bristow C.S. (eds.) Braided Rivers. London, Geol. Soc. Spec. Publ. 75, p. 147-162.

Tunbridge I.P. 1981. Sandy high-energy flood sedimentation - some criteria for recognition, with an example from the Devonian of S.W. England. Sedimentary Geology, 28:79-95.

Manuscrito ID 15454 Submetido em 20 de setembro de 2009 Aceito em 13 de outubro de 2011 